\title{
Fluvial response to environmental conditions during MIS 4-3: a sedimentary record at the Brześnica site, central-western Poland
}

\author{
Damian MOSKALEWICZ ${ }^{1, *}$, Karol TYLMANN², Piotr Paweł WOŹNIAK ${ }^{1}$, Natalia KOPYŚĆ ${ }^{1}$ \\ and Piotr MOSKA ${ }^{3}$ \\ 1 University of Gdańsk, Department of Geomorphology and Quaternary Geology, Bażyńskiego 4, 80-309 Gdańsk, Poland \\ 2 University of Gdańsk, Department of Geophysics, Piłsudskiego 46, 81-378 Gdynia, Poland \\ 3 Institute of Physics - Centre for Science and Education, Konarskiego 22B/216, 44-100 Gliwice, Poland
}

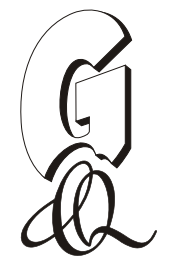

Moskalewicz, D., Tylmann, K., Woźniak, P.P., Kopyść, N., Moska, P., 2020. Fluvial response to environmental conditions
during MIS 4-3: a sedimentary record at the Brześnica site, central-western Poland. Geological Quarterly, 64 (4): 915-930, doi: $10.7306 / g q .1560$

Associate Editor: Wojciech Granoszewski

Fluvial deposits subjected to this study are exposed at the Brześnica site, in the south-western part of the Wielkopolska region in Poland, which was close to the ice-sheet limit during the Last Glacial Maximum (LGM). Sedimentological analyses, including lithofacies descriptions, palaeocurrent measurements, grain size and rounding analyses and heavy mineral compositions indicate that the fluvial deposits at Brześnica were deposited in braided river environment. The following fluvial sedimentary processes were inferred: (1) shallow, rapid flow alternating with waning flow, (2) infilling of erosional channels with fluvial sediments during flood events, (3) changes from supercritical to subcritical flows, and (4) shallow sheet floods. The results of OSL dating indicated sediment deposition $\sim 65.2 \pm 1.5 \mathrm{ka}$, i.e. in MIS 4 , that was here characterized by cold environmental conditions and a general shift from meandering to braided fluvial sedimentation style. This finding contrasts with accumulation/erosion phases interpreted previously in this region for that time interval; however, it is consistent with recent studies of fluvial systems functioning during MIS 5-2 and of factors responsible for sedimentation style.

Key words: braided river, fluvial deposits, OSL dating, MIS 4, MIS 3, Last Glacial Maximum.

\section{INTRODUCTION}

Fluvial archives are the main component of the continental sedimentary record in geological formations of any age (Miall, 1996). During the Pleistocene, a large part of the continental Europe was covered by successive ice-sheets. Fluvial successions are commonly found intercalated with glacial and fluvioglacial deposits related to various ice-sheet advances (e.g., van Huissteden and Kasse, 2001; Eismann, 2002; Vandenberghe, 2003; Zieliński, 2007; Kenzler et al., 2015; Weckwerth, 2018). Fluvial sedimentary record may be a result of many factors, among which the most important are: regional topography, influence of climate, discharge characteristics, base level changes, and sediment supply (e.g., Miall, 1996; Blum and Törnqvist, 2000; Bridge and Demicco, 2008; Colombera and Mountney, 2019). Thus, fluvial archives are a valuable data source for palaeogeographical reconstructions, because the

\footnotetext{
* Corresponding author, e-mail: damian.moskalewicz@ug.edu.pl
} Received: May 18, 2020; accepted: July 10, 2020; first published online: October 12, 2020 depositional record is responsive to many environmental factors. For example, in the Pleistocene sedimentary record, long-term climate changes related to Milankovitch cycles are primarily expressed as glacials and interglacials (Hays et al., 1976). This leads to e.g., global or regional base level changes which may force particular fluvial sedimentation styles and channel distribution geometries (amalgamated channel-fills of braided rivers during regression and isolated channel-fills of meandering or anastomosing rivers during transgression as a general simplification) or widespread subaerial erosion (Shanley and McCabe, 1993, 1994). On a shorter timescale, climate change between successive glaciations (colder or warmer periods) modify the environment of the catchment area (e.g., vegetation cover, discharge, sediment supply) which control basic river parameters, sedimentation styles and rates of erosion (Macklin et al., 2012). For example, climate change from colder to warmer conditions, resulting in reforestation and decreasing rates of erosion, may lead to a shift from a braided to meandering sedimentation style (Leigh, 2006).

Rivers which functioned between successive glaciations both within glaciated areas or on ice-sheet forelands are of special interest, because they were subject to rapid environmental changes (e.g., Huisink, 1997; Houben, 2003; Busschers et al., 2008). Unfortunately, the Pleistocene sedimentary record con- 


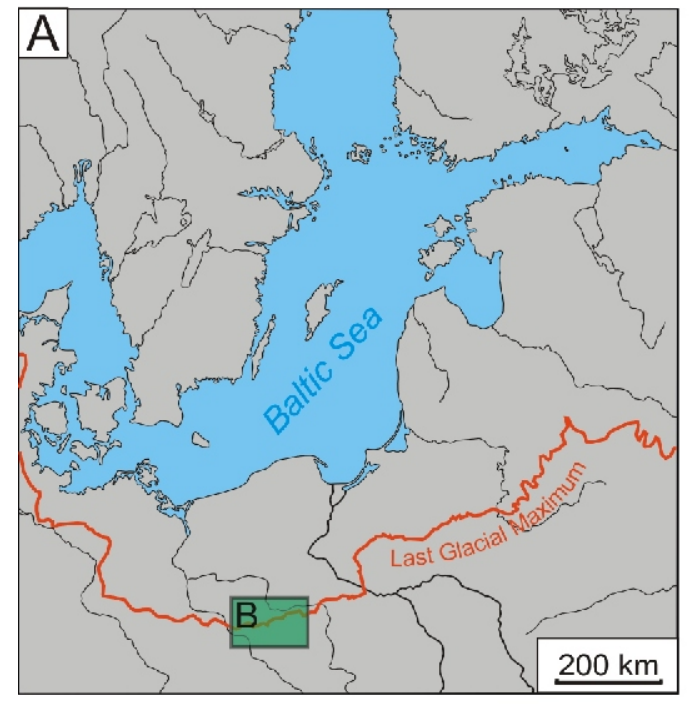

ice-sheet limit during Warthe Stadial (MIS 6)

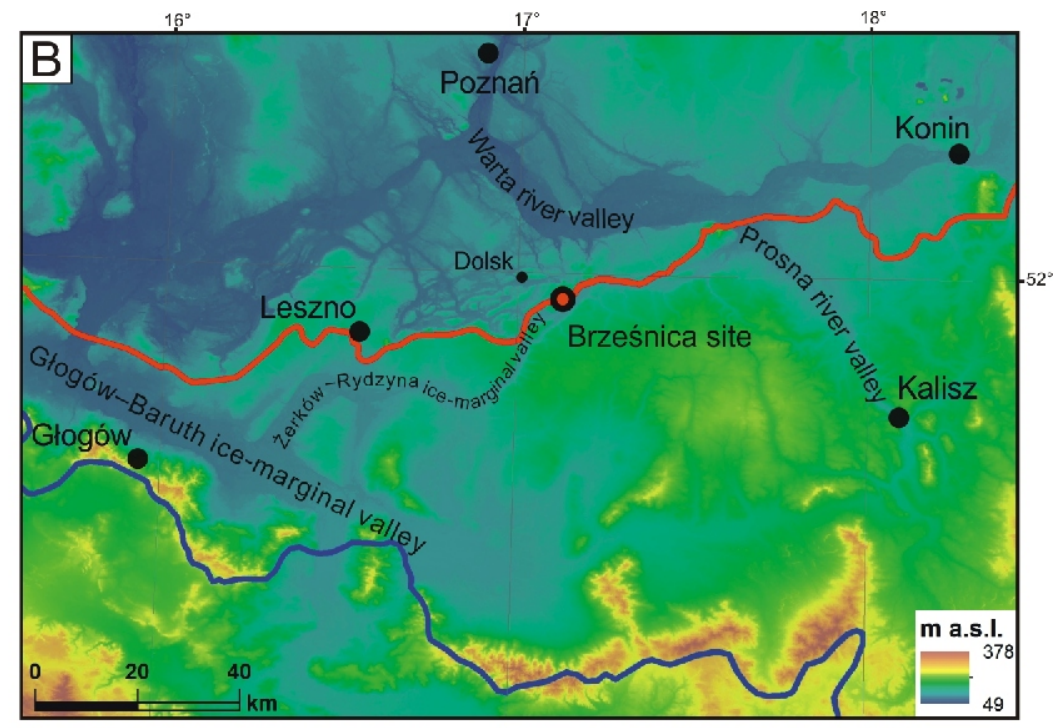

ice-sheet limit during Last Glacial Maximum (MIS 2)

Fig. 1. Location of the study site

A - location relative to the LGM ice-sheet limit in Central Europe; B - location on the southern Great Polish Lowland. The ice-sheet limits are based on the Polish Geological Map 1:500,000 (http://geologia.pgi.gov.pl), DEM visualised with Digital Terrain Elevation Data, level 2, based on digitized topographic maps 1:50,000

tains multiple stratigraphic gaps which make difficulties in the continuous reconstruction of fluvial sedimentation style, erosion phases for that period, or interpretation of the palaeogeography for particular time span (Mol et al., 2000; Marks, 2004). Another problem is related to the influence of downstream and upstream factors on fluvial sedimentation. How the inland limit of base-level changes has impacted on the evolution of river patterns in the past may be unclear (Catuneanu, 2006). New findings in these fields may improve our understanding of fluvial processes during Pleistocene climate changes and constrain palaeogeographical models (van Huissteden et al., 2001; Krzyszkowski and Kuszell, 2007; Dzieduszyńska et al., 2020).

During investigation of the timing and extent of the Scandinavian Ice Sheet in Poland during the Last Glacial Maximum (LGM; Tylmann et al., 2019) a new site of Late Pleistocene fluvial deposits was found near the LGM ice-sheet limit in central-western Poland (Fig. 1). Considering its location and geological context, both the morphostratigraphic (near the LGM ice-sheet limit) and the lithostratigraphic (below glacial deposits of MIS 2 age), this site offers new evidence for regional river system evolution in the Late Pleistocene, and provides data on evolution of the fluvial sedimentary record during past dynamic environmental changes.

This study analyses how a fluvial sedimentary system located in the upstream part of a catchment area reacted to environmental and palaeogeographical conditions during MIS 4 and MIS 3 in terms of sedimentation style and depositional record. Fluvial deposits have been documented previously in central and south-western Poland, mainly for MIS 3 and MIS 2, while MIS 4 relates to a gap in the sedimentary record (e.g., Krzyszkowski and Kuszell, 2007). As we show below, post-MIS 5 phases of fluvial erosion and accumulation here are not well understood. Our findings, compared to other recently published data (e.g., Dzieduszyńska et al., 2020), put new light on this issue.

\section{REGIONAL SETTING}

The study site is located in the southern part of the Great Polish Lowland of Central Europe, only a few hundreds of metres south of the line of the maximum ice-sheet extent during the Last Glacial Maximum (MIS 2; see Fig. 1B). It is situated in the Obra River valley, on a fluvioglacial terrace of the former Żerków-Rydzyna ice-marginal valley (Szałajdewicz, 2002). According to Rotnicki (1987) this is a cut-in and then built-up terrace of MIS 2 age as its origin is related to the ice-marginal sandur, similarly to terrace III (110 m a.s.I.) in the Prosna River valley (Fig. 1B). The ice-marginal valley was the outflow route for glacial meltwater and extraglacial water to the south-west (see Figs. 1B and 2), to the Głogów-Baruth ice-marginal valley (Krzyszkowski and Kuszell, 2007). South of the valley a flat moraine plateau of Saalian (MIS 6) age is present (Fig. 2). During the Late Weichselian (MIS 2) the ice-sheet margin, located to the north of the valley, started to melt not later than $21.8 \pm 1.8 \mathrm{ka}$, as suggested by the ${ }^{10} \mathrm{Be}$ surface exposure age of an erratic resting on the Weichselian moraine plateau (Tylmann et al., 2019; for the position of the boulder see Figs. 2 and 5).

The detailed maximum extent of the last ice-sheet in the study area as well as the time when the Żerków-Rydzyna ice-marginal valley started to form are disputable. End moraines are absent there and the well-developed ice-marginal zone with terminal moraines is recognized a few kilometres to the north of the ice-marginal Obra valley, in the vicinity of Dolsk (Figs. 1B and 2). These moraines contain glaciotectonically-upthrusted Miocene deposits (Szałajdewicz, 1998). They occur in the vicinity of tunnel-valley lakes and sandar that south of them locally cut moraine plateaus. According to Szałajdewicz (1998) some of the plateaus are of Late Weichselian (MIS 2) age, while others are Saalian (MIS 6) age (Fig. 2). However, the Żerków-Rydzyna ice-marginal valley could finally form only 


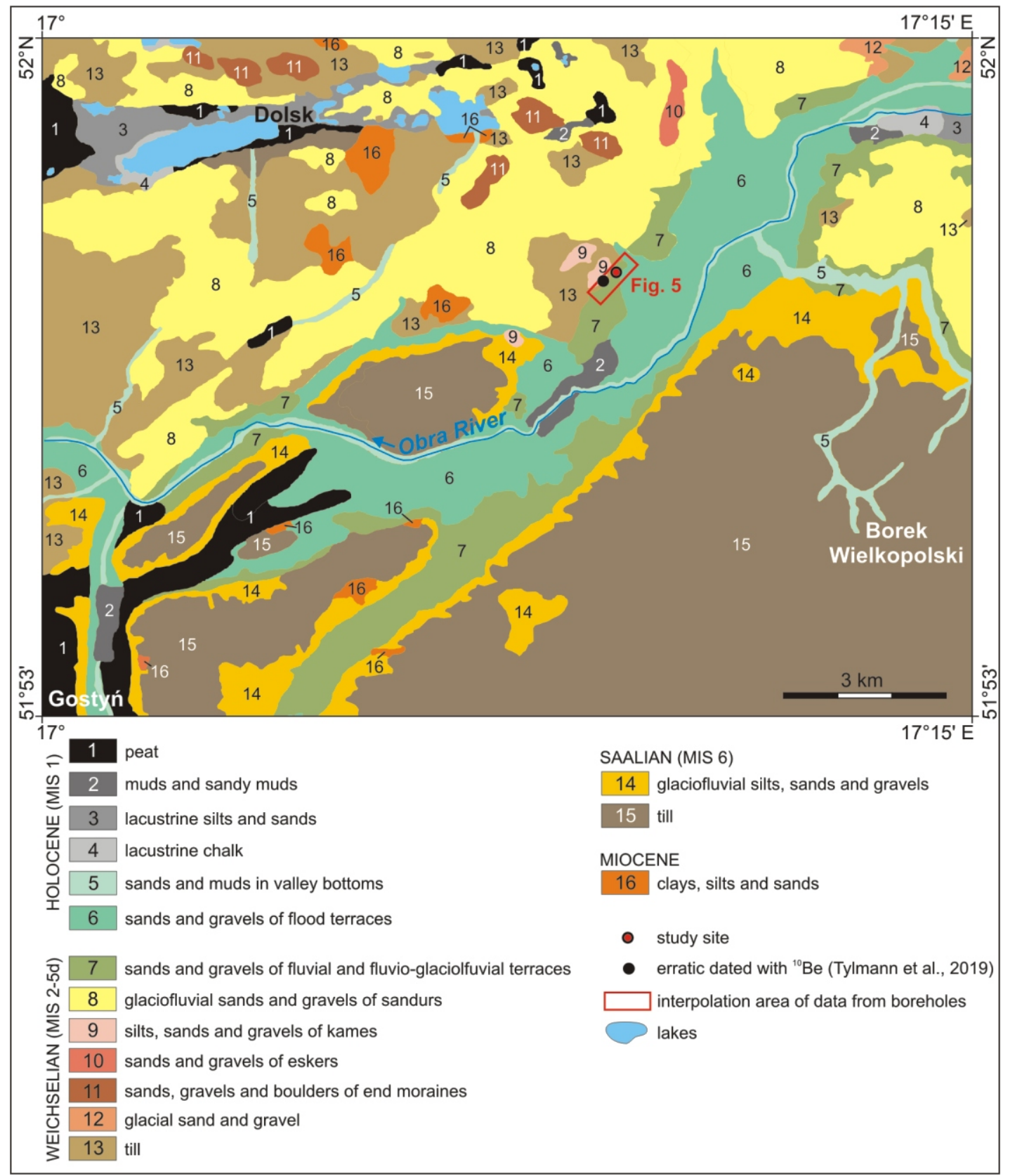

Fig. 2. Surface deposits in the surroundings of the Brześnica site based on data acquired from the PGI-NRI database (http://geologia.pgi.gov.pl)

during this younger, post-maximum stage of the ice-sheet buildup/recession, because earlier (i.e. the time of maximum ice-sheet extent during the LGM), ice still covered the eastern parts of the valley area (cf. Czerwonka and Krzyszkowski, 1994).

The Żerków-Rydzyna ice-marginal valley (presently the Obra River valley) is $4 \mathrm{~km}$ wide. The valley floor is located at $90 \mathrm{~m}$ a.s.I. in the northern, and at $80 \mathrm{~m}$ a.s.l. in the southwestern part of the valley. The terrace with the study site is located 8-10 $\mathrm{m}$ above the valley floor. Along the southern slope of the valley the terrace is narrow and continuous, while on the northern slope (where the study site is located) it consists of small, isolated patches (compare areas marked with number 7 in Fig. 2).

\section{METHODS}

\section{FIELD WORKS}

The sedimentary features of the deposits were documented in the exposure, within a sand exploration pit, with standard sedimentological techniques of lithofacies description and measurements (Fig. 3). The sedimentary succession is shown on standard sedimentological logs with thickness and grain-size scales, appropriate graphic symbols for lithofacies, and other sedimentary features (Fig. 3). Lithofacies codes according to Zieliński $(1998,2017)$ were used to identify structural and textural features of the deposits. Palaeocurrent directions were measured based on the dip directions within cross-stratified 
and cross-laminated lithofacies. Twenty-five samples were taken for textural and mineralogical laboratory analyses. Seven of them were also used for optically stimulated luminescence (OSL) dating (Fig. 3C). They were collected from sandy sediment layers in profile $\mathrm{Br} 1$ by driving plastic tubes into the vertical exposure.

\section{LABORATORY ANALYSES}

Laboratory work included grain size analyses, heavy mineral composition, quartz grain rounding and OSL dating. For determination of grain size parameters, sieve analysis was carried out after drying collected samples at $105^{\circ} \mathrm{C}$ for 12 hours. A sieve column with mesh sizes of 16 to $0.0625 \mathrm{~mm}$ at $0.5 \phi$ ntervals was used for the analysis. The sediments fractions adopted are from the Wentworth \& Udden scale (Udden, 1914; Wentworth, 1922). Statistical parameters of the grain size distribution, such as mean grain size, sorting (standard deviation), skewness, and kurtosis were calculated according to the Folk and Ward (1957) method with GRADISTAT software (Blott and Pye, 2001).

Quartz sand fractions of 0.71 to $1 \mathrm{~mm}$ and 0.5 to $0.71 \mathrm{~mm}$ were analysed for their rounding using a binocular microscope according to the visual scale of Powers (1953). Samples were washed with $10 \% \mathrm{HCl}$ to remove carbonates and then with distilled water to clean grains. At least 100 quartz grains per sample were classified into one of six rounding classes: very angular (VA), angular (A), sub-angular (SA), sub-rounded (SR), rounded $(R)$ and well rounded (WR). Within $S R, R$ and WR classes, broken grains (grains which lost at least $\sim 30 \%$ of volume as a result of crushing) were also identified. Crushing index $(\mathrm{Cl})$ and roundness index $(\mathrm{RA})$ were calculated as a percentage of broken grains and VA + A grains in a sample respectively (Olsen, 1983). The $0.125-0.25 \mathrm{~mm}$ fraction was used to establish the heavy mineral composition. Each sample was washed with $10 \% \mathrm{HCl}$ to dissolve carbonate cements, and then sodium polytungstate $\left(3 \mathrm{Na}_{2} \mathrm{WO}_{4} \cdot 9 \mathrm{WO}_{4} \cdot \mathrm{H}_{2} \mathrm{O}\right)$ with a specific density of $2.85 \mathrm{~g} \cdot \mathrm{cm}^{-3}$ (Mange and Maurer, 1992) was used to separate heavy minerals from the light fraction. The heavy fraction was immersed in Canada balsam (refractive index of 1.522) on standard microscope glass slices. The main analysis was carried out on a Zeis Axio Imager A2 petrographic microscope and the following groups were identified: opaques (OPQ), amphiboles (AMP), pyroxenes (PYR), garnets (GRT), epidotes (EPI), chlorites (CHL), staurolites (STA), tourmalines (TOU), zircon (ZRT), biotite (BIO), muscovite (MUS), titanite (TIT), rutile (RUT), glauconite (GLA), sillimanite (SIL), andalusite (AND), kyanite (KYA), apatite (APA), and other (OTH) rarely occurring minerals. Heavy mineral contents were used in cluster analysis to improve interpretation of the results obtained. Euclidean distances using the Ward method (Ward, 1963) were used in an agglomeration process to minimize internal differentiation of clusters of lower hierarchical order.

OSL samples were prepared both for gamma spectrometry and luminescence measurements. The analysis took place in the Gliwice Absolute Dating Methods Centre (GADAM) at the Silesian University of Technology. High-resolution gamma spectrometry using a HPGe detector was used to determine the contents of $\mathrm{U}$, Th and $\mathrm{K}$ in the samples. Prior to these measurements, the samples were stored for three weeks to ensure equilibrium between gaseous ${ }^{222} \mathrm{Rn}$ and ${ }^{226} \mathrm{Ra}$ in the ${ }^{238} \mathrm{U}$ decay chain. Each measurement lasted for at least 24 hours. The activities of the isotopes present in the sediment were determined using the IAEA standards RGU, RGTh, RGK after subtracting the background value from the detector. Dose rates were calcu- lated using the conversion factors of Guerin et al. (2011). Water content was adopted at the level of $10 \pm 3 \%$ for all samples. The method of Prescott and Stephan (1982) was used for the cosmic ray beta dose rate calculation. For OSL measurements, 0.125 to $0.2 \mathrm{~mm}$ grains of quartz were extracted and standard chemical procedures applied (Aitken, 1998) in the following order: first the sediment samples were treated with $20 \%$ hydrochloric acid $(\mathrm{HCl})$ and $20 \%$ hydrogen peroxide $\left(\mathrm{H}_{2} \mathrm{O}_{2}\right)$ to remove carbonates and organic matter. Next the quartz grains were separated using density separation with the application of sodium polytungstate solution leaving grains of densities between 2.62 and $2.75 \mathrm{~g} \cdot \mathrm{cm}^{-3}$. The grains were sieved, before etching with concentrated hydrofluoric acid (HF, $60 \mathrm{~min}$ ). An automated Risø TL/OSL DA-20 reader was used for the OSL measurements of multi-grain aliquots (25.5 on average), each weighing $\sim 1 \mathrm{mg}$. The stimulation light source was a blue light $(470 \pm 30 \mathrm{~nm})$ emitting diode (LED) array delivering $50 \mathrm{~mW} \cdot \mathrm{cm}^{-2}$ to the sample. Detection was through $7.5 \mathrm{~mm}$ of a Hoya U-340 filter. Equivalent doses were determined using the single-aliquot regenerative-dose (SAR) protocol (Murray and Wintle, 2000) and the CAM (central age model, Galbraith et al., 1999) model was used to estimate the final value.

\section{PROCESSING OF GEOLOGICAL DATA}

Surface geological maps and borehole profiles for the study area were acquired from Polish Geological Institute - National Research Institute databases. An archived borehole dataset was used to interpolate the altitude of the top and the bottom of the fluvial sequence analysed. Interpolation was based on the Kriging method using ESRI ArcMap 10.2 software, while for determining the gradient of the bottom surface of the fluvial strata the polynomial method (1st polynomial) was used. Palaeocurrent results were processed using Stereonet software. Rose diagrams were created and statistical parameters of orientation (mean vector with 95\% confidence interval and coefficient of compactness) were calculated.

\section{RESULTS AND INTERPRETATION}

LITHOFACIES AND PALAEOCURRENTS DESCRIPTION

The sedimentary sequence exposed at Brześnica was studied in three neighbouring sections and documented in sedimentological logs (Fig. 3A). It is up to $6 \mathrm{~m}$ thick and consists of sand and gravel deposits overlain by a diamictic layer of varying thickness (Fig. 3B). These deposits lie on muds, which were observed $\sim 1$ m below the exposed section. The whole sedimentary sequence was divided into four sedimentological units reflecting various lithological features of the deposits. Unit UO relates to scarcely exposed muds, unreachable for lithofacies analysis. Unit U1 consists of sand and gravel deposits of thickness from $>2.5$ to $>3.5 \mathrm{~m}$; unit U2 is diamicton and gravel of thickness $<0.5 \mathrm{~m}$; unit U3 represents the uppermost part of the sequence which is a diamictic layer $0.2-2.0 \mathrm{~m}$ thick (Fig. 3B). The main part of the sequence analysed is unit $\mathrm{U} 1$ which, based on textural and structural characteristics of the deposits, was divided into three subunits: U1a, U1b and U1c.

Subunit $U 1 a$ is exposed in the lower parts of each profile (Fig. 3C-E) and reveals cyclic transition between dominant lithofacies: from horizontally stratified fine and medium sand $(\mathrm{Sh})$ to ripple cross-laminated fine and medium sand $(\mathrm{Sr})$. 


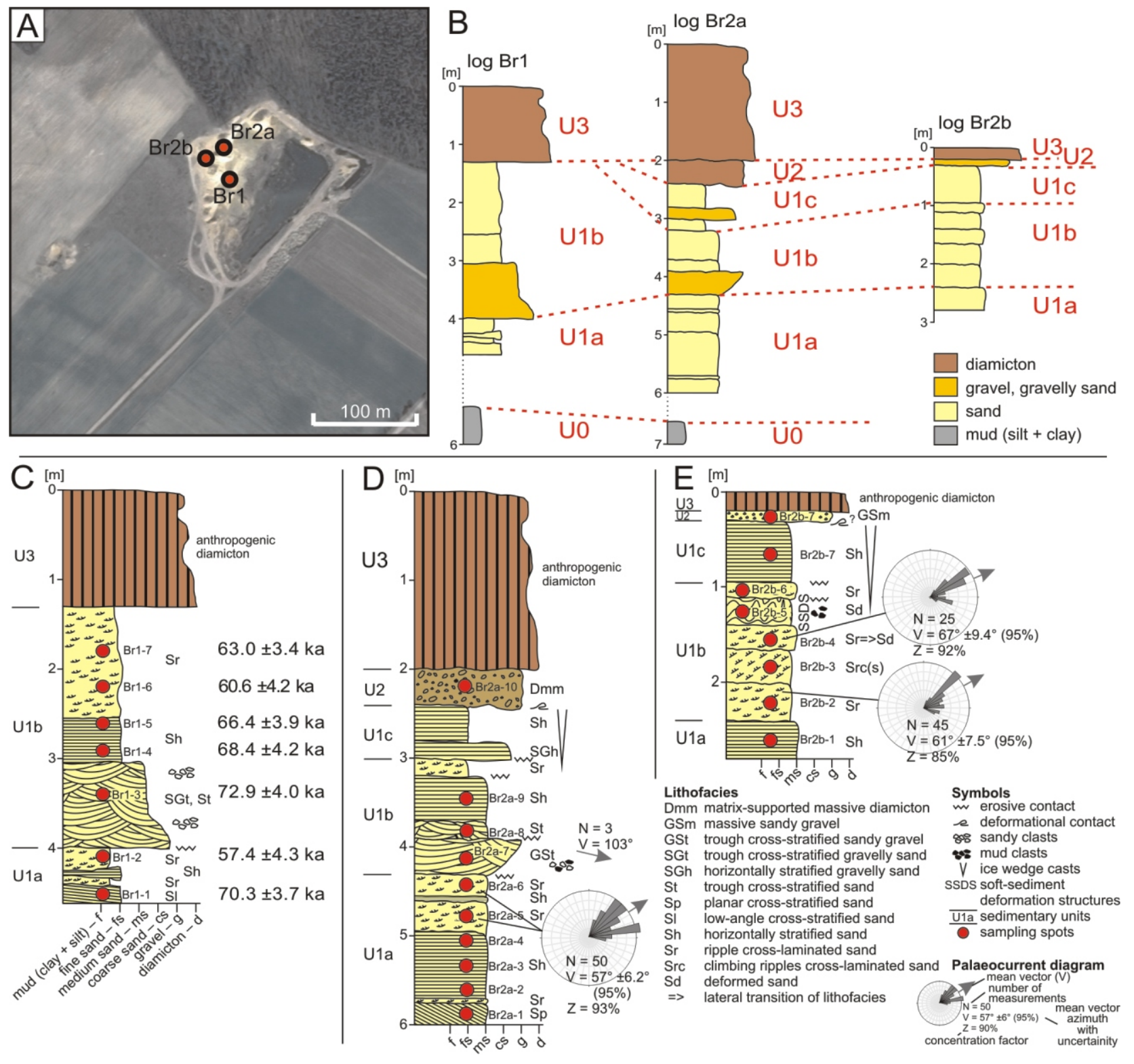

Fig. 3. Sedimentological profiles investigated at the Brześnica site

A - location of the profiles in the exploration pit; source of the ortophotomap: http://geologia.pgi.gov.pl; B - correlation of the profiles with recognized geological units. Unit $\mathbf{0}$ was identified below the exploration level and is not exposed in the section; $\mathbf{C}-\mathbf{E}-$ detailed sedimentological logs of the profiles: $\mathrm{Br} 1, \mathrm{Br} 2 \mathrm{a}$, and $\mathrm{Br} 2 \mathrm{~b}$, respectively

The thickness of the whole subunit is up to $1.6 \mathrm{~m}$, while the individual lithofacies vary in thickness from 5 to $75 \mathrm{~cm}$. The palaeocurrent direction measured in ripple cross-laminated beds shows palaeoflow towards the NE with a mean vector of $57^{\circ} \pm 6.2^{\circ}$ and a $93 \%$ concentration factor (Fig. 3D).

Subunit U1b (Fig. 3C-E) is a 1.3-2.7 m thick sequence which also reveals a cyclic transition of lithofacies: from trough cross-stratified gravely-sand and coarse sand, through horizontally-stratified fine and medium sand to ripple cross-laminated fine sand (SGt, St $\rightarrow \mathrm{Sh} \rightarrow \mathrm{Sr}$ ). This kind of lithofacies cycle is exposed in profiles $\mathrm{Br} 1$ and $\mathrm{Br} 2 \mathrm{a}$ (Fig. 4A, B), but in profile $\mathrm{Br} 2 \mathrm{~b}$ it changes laterally into a cycle consisting of ripple cross-laminated fine/medium sand $(\mathrm{Src}=>\mathrm{Sr}$ ). The thickness of the individual lithofacies in this subunit varies from $5 \mathrm{~cm}$ to $1.2 \mathrm{~m}$. The contact of lithofacies GSt with the underlying deposits of subunit $\mathrm{U} 1 \mathrm{a}$ is erosional (Fig. 4A). Within lithofacies GSt, angular clasts of sand with internal stratification and muddy deformed clasts were recognized (Fig. 4C, D). Three measurements of the cross-strata dip direction within the GSt lithofacies show palaeoflow towards the ESE with a mean vector of $103^{\circ}$. The palaeocurrent direction measured in ripple cross-laminated beds exposed in the profile $\mathrm{Br} 2 \mathrm{~b}$ also shows palaeoflow towards the NE with mean vectors of $61^{\circ} \pm 7.5^{\circ}$ and $67^{\circ} \pm 9.4^{\circ}$ and concentration factors of 85 and $92 \%$ respectively (Fig. $3 \mathrm{E}$ ). The deposits of subunit $U 1 \mathrm{~b}$ are partly deformed (Fig. 4F), the primary ripple cross-lamination being contorted. Additionally, load casts with co-shaped internal lamination and a single structure with cone intersection thinning upwards were recognized in this subunit. Central part of the latter structure contains extremely contorted lamination, while close to its margins and at the top, semi-vertical, co-shaped lamination is clearly visible (Fig. 4F). 


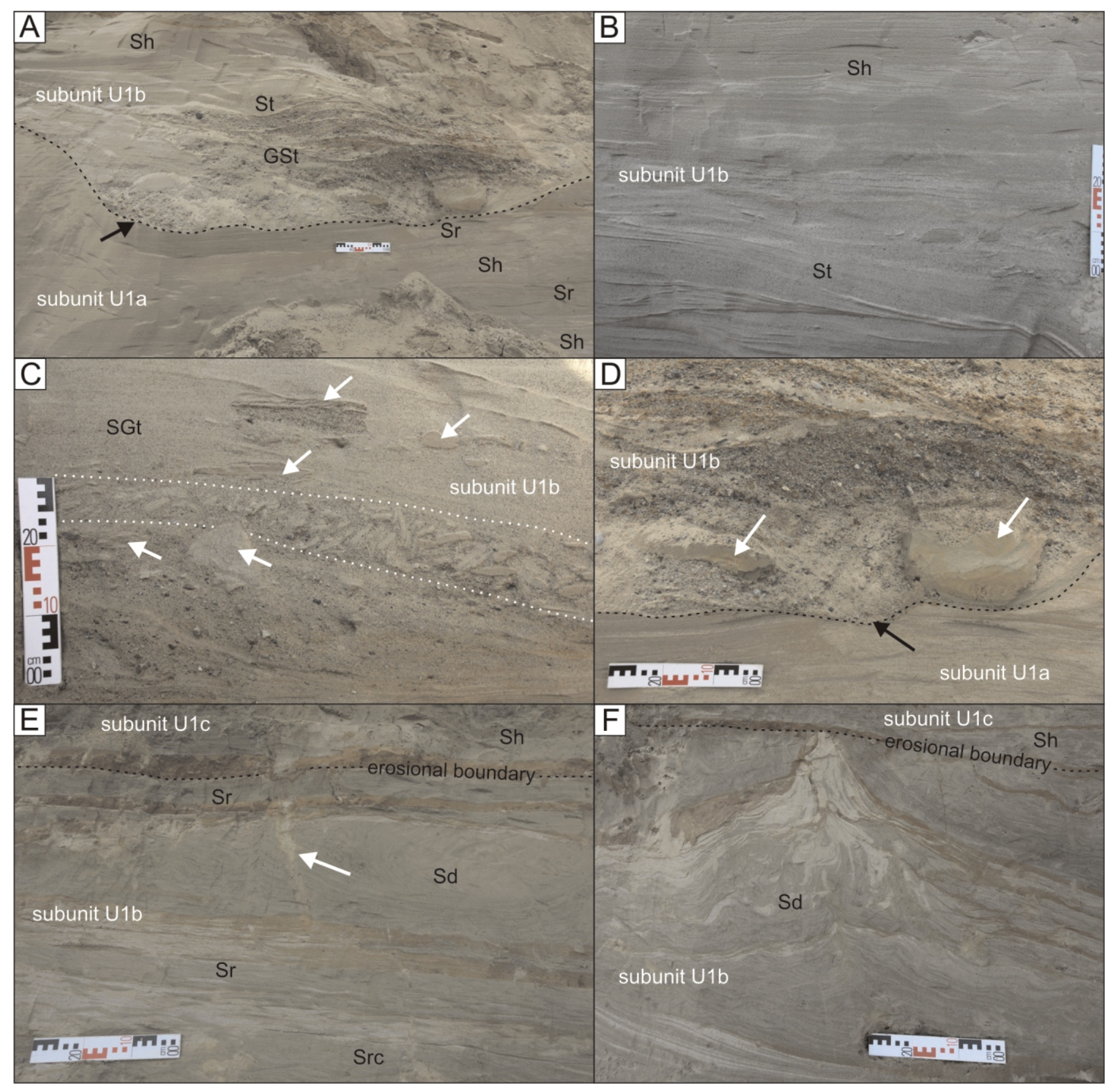

Fig. 4. Details of sedimentary features recognized at the Brześnica site

A - sharp erosional boundary (arrowed) in the bottom of channel-fill dividing fluvial units U1a and U1b; B - common transition of St to Sh lithofacies in the studied sedimentary sequence; $\mathbf{C}$ - sandy intraclasts with sharp edges (zone of numerous imbricated clasts indicated by dotted lines and single clasts indicated by arrows) being a result of their transport in a frozen state; $\mathbf{D}$ - detailed view of intraclasts with preserved internal structure (indicated by white arrows), built of sediment similar to that visible below the erosional boundary indicated by the black arrow, this shows the incorporation of frozen sandy bodies within the same fluvial system; $\mathbf{E}$ - sandy ice-wedge cast recognized in the upper part of the fluvial sedimentary sequence indicating permafrost conditions; $\mathbf{F}$ - soft-sediment deformation structures (contorted lamination and sandy volcano) in subunit $\mathrm{U} 1 \mathrm{~b}$; other explanations as on Figure 3

Subunit U1c was recognized as the uppermost part of the unit $\mathrm{U} 1$ in profiles $\mathrm{Br} 2 \mathrm{a}$ and $\mathrm{Br} 2 \mathrm{~b}$ (Fig. 3D, E). It consists of horizontally stratified gravely sand and fine to medium sand (SGh, $\mathrm{Sh}$ ), up to $63 \mathrm{~cm}$ thick, with an erosional boundary at the bottom. This subunit is covered with deposits of unit U2, which consists of $10 \mathrm{~cm}$ of massive sandy gravel (GSm) and $40 \mathrm{~cm}$ of matrix-supported, massive diamicton (Dmm). Lithofacies GSm, observed in profile $\mathrm{Br} 2 \mathrm{~b}$, changes laterally to a thicker lithofacies Dmm in profile Br2a (Fig. 3D, E). The uppermost part of the sedimentary sequence in each profile is unit U3. It con- sists of very poorly sorted, massive and diamictic sediment with a small admixture of organic matter. This deposit is recognized as a matrix-supported, homogeneous diamicton layer that varies in thickness.

\section{INTERPRETATION}

Lithofacies Sh, one of the two main lithofacies recognized in the lower part of each profile (subunit U1a), might have formed in upper plane bed conditions or during very shallow and stable 


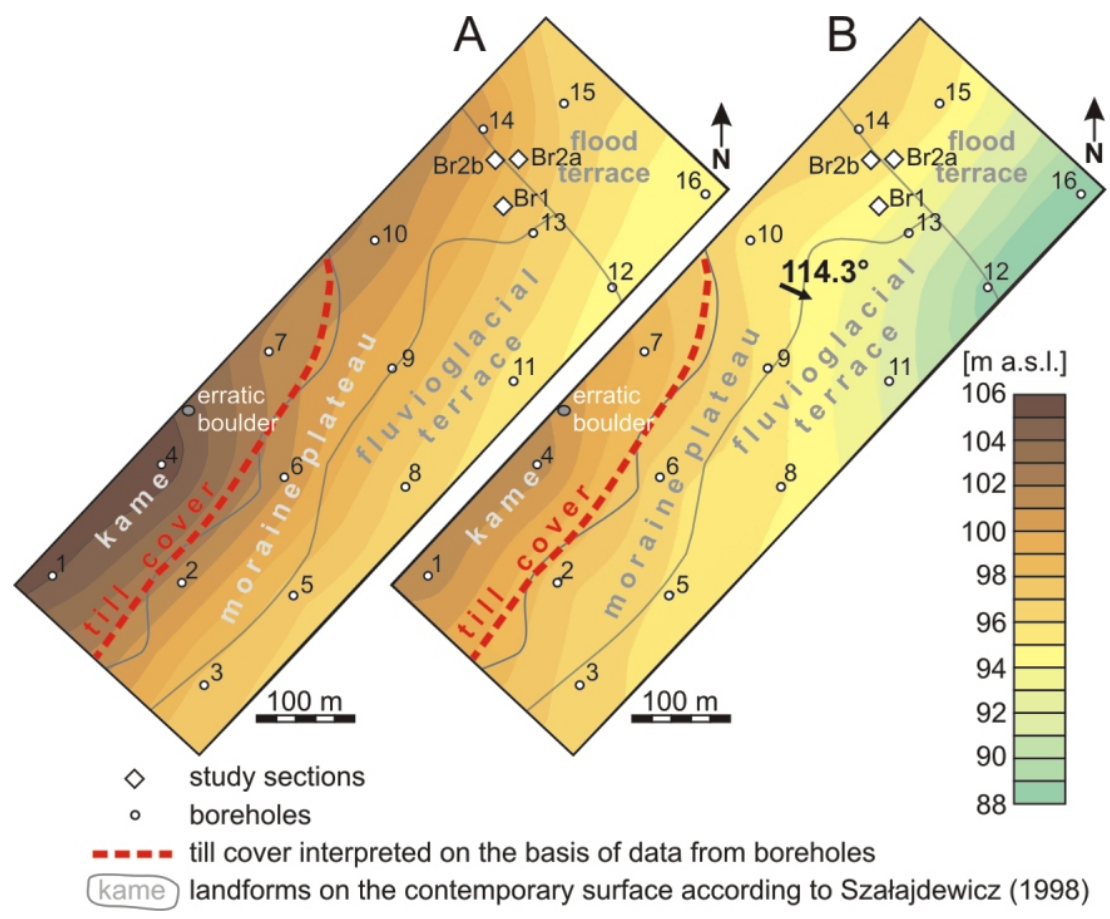

Fig. 5. Relief of the top (A) and basal (B) part of the sandy fluvial succession (Unit 1); polynomial analysis indicated the gradient of the base surface is directed to the ESE with azimuth of $114.3^{\circ}$, interpolation based on data acquired from the PGI-NRI database (http://geologia.pgi.gov.pl)

flows (Miall, 1996). Its cyclic change to Sr lithofacies suggests transition from upper plane bed conditions with flows of $\sim 1 \mathrm{~m} / \mathrm{s}$ velocity and $0.5 \mathrm{~m}$ depth to flows of lower velocity (Ashley, 1990). A lack of coarser sediment and tabular strata in each profile indicate a wide zone of shallow flows with an undefined main channel, which may be the result of deposition by flood events on any sand-bed river floodplain or wide interchannel bar system (cf. Zieliński, 1998, 2017).

The vertical and lateral change of lithofacies in subunit U1b as well as the sharp-edged blocks of sand with preserved internal structure and the muddy intraclasts within the lithofacies GSt, indicate a sedimentary record of erosional channels being infilled during the flood events and conditions changing from supercritical to subcritical flows. It also reveals that sediment incorporated into the channel was frozen and therefore deposition took place in cold climate conditions. Similar lithofacies transitions are known from both meandering and braided rivers (e.g., Blazauskas et al., 2007; Bride and Demicco, 2008; Sokołowski et al., 2019). The wide extent of the channel deposits, the low content of climbing ripple cross-lamination and the very fine grained lithofacies recognized in the section, suggest that deposition in braided river environment is more likely (cf. Zieliński, 2007). Subunit U1a also shows features related to braided river system as it seems to have formed in a wide interchannel bar system. The origin of subunit U1c is similar to that of subunit $\mathrm{U} 1 \mathrm{a}$, as their lithofacies were formed in upper plane bed conditions. Sandy ice wedge casts within these lithofacies indicate periglacial conditions after deposition of the braided river sediments (e.g., Eissmann, 2002; Vasil'chuk et al., 2018).

Soft-sediment deformation structures (SSDS) recognized in subunit U1b can be explained as an effect of the downward propagation of permafrost on a valley slope. In such conditions, unfrozen or temporarily melted frozen sediments, below the still-frozen sediments, were liquefied. This caused loading pro- cesses (contorted lamination and load casts), but also, with the rise of ground-water pressure (due to melting combined with sediment creep on a slope) fluidized sediment moved upwards and a sand volcano was formed (Fig. 4F). The SSDS described seem not to be linked to an alternative trigger such as a seismic event, as movement on a near-surface gravity slide is sufficient to generate such deformation (Owen and Moretti, 2008), here additionally enhanced by periglacial conditions (cf. van Vliet-Lanoë et al., 2004). The deformation structures in subunit U1b developed before the deposition of subunit U1c, as indicated by the erosional contact of the subunits; prior to that, the sediments of subunit $\mathrm{U} 1 \mathrm{~b}$ were cut by ice wedge casts, protruding downwards from top of the subunit U1c (cf. Figs. 3E and 4F).

Palaeocurrent analysis of Unit 1 indicates river flow generally to the east (between NE to ESE). The low scattering of results of measurements from the ripple cross-laminated sands indicate low sinuosity, consistent with a braided river environment. Three measurements from tabular cross-strata showed flow roughly to the east $\left(103^{\circ}\right)$ with $\sim 35-45^{\circ}$ deviation from the ripple cross-laminated sediment. Analysis of the fluvial succession of Unit 1 in the vicinity of the profiles studied, based on boreholes, shows that its base is generally inclined towards the ESE (Fig. 5). The trend of the dip direction for the planar surface approximating the base of the unit is $\sim 114^{\circ}$ (Fig. 5B). Additionally, tabular strata $0.5-1 \mathrm{~m}$ thick (lithofacies SGt, St) indicate a flow depth of $\sim 1-3 \mathrm{~m}$ in the central part of the channel (Bridge, 2003).

The diamicton within unit U2 (Fig. 5) is probably a gravity flow deposit, being the record of redeposition of weathered glacial till from the slope above. It was formed by gravity flows of diamictic, morainic material on the gently inclined slope of the river valley. A lateral change in lithofacies (Dmm => GSm) suggests differentiation of gravity flow within the slope or/and its transition during flow along the slope profile - from characterized by cohesive matrix, where en masse and laminar transport 
is typical, to being more water-saturated and fines-depleted, where turbulence occurred (cf. Haughton et al., 2009). Additionally, source material changeability might have led to different gravity flow processes. The content of coarser particles without clear directional features in the Dmm lithofacies may indicate slow slope processes in periglacial conditions (Schwan et al., 1982).

Unit U3 (Fig. 5) is an anthropogenic diamicton. This deposit was formed due to agricultural reworking of a Holocene soil profile developed probably within weathered glacial till. In the thickest part, evidence of mechanical pushing of deposits to forming a low heap was observed.

\section{GRAIN SIZE AND QUARTZ ROUNDING}

DESCRIPTION

The sedimentological units are sand-dominated. In subunit U1a the sand fraction content varies from 96.1 to $99.7 \%$. In most samples, fine and medium-grained sand dominates (46.2-68.7\% and $5.7-43.4 \%$ respectively); the content of very fine sand varies from 3.4 to $25.7 \%$ and the amount of coarse and very coarse sand is $<0.5 \%$. The mean grain diameter varies from 0.15 to $0.24 \mathrm{~mm}$ and no clear trends within the profiles or differences between lithofacies $\mathrm{Sh}$ and $\mathrm{Sr}$ were observed (Fig. 6A). The deposits are moderately well-sorted with standard deviation from 0.47 to $0.6 \phi$. Their grain-size distributions are slightly fine-skewed $\left(S_{k}\right.$ varies from 0.02 to $\left.0.14 \phi\right)$ and mesokurtic $\left(K_{g}\right.$ varies from 0.94 to $\left.1.04 \phi\right)$.

Deposits of subunit U1b are also sand-dominated (64.6-99.8\%). In profile $\mathrm{Br} 1$ and $\mathrm{Br} 2 \mathrm{a}$ this subunit reveals a clear fining-upwards trend. The lower part of the subunit in profile $\mathrm{Br} 1$ is dominated by medium and fine-grained sand (51.3 and $31.6 \%$, respectively) and its upper part is dominated by fine and very fine-grained sand ( 73.5 and $19.6 \%$, respectively). In profile $\mathrm{Br} 2 \mathrm{a}$ the bottom part is dominated by gravel $(35.2 \%)$ and very coarse, coarse and medium-grained sand $(21.0,19.6$ and $14.4 \%$, respectively), whereas the top part is dominated by fine and medium-grained sand (72.4 and $17.7 \%$, respectively). In both profiles the mean grain diameter decreases upwards from 0.3 to $0.16 \mathrm{~mm}$ in profile $\mathrm{Br} 1$ and from 1.19 to $0.19 \mathrm{~mm}$ in profile $\mathrm{Br} 2 \mathrm{a}$ (Fig. 6A). Sorting increases upwards within the subunit, as shown by a decrease in standard deviation from 0.7 to $0.5 \phi$ in profile $\mathrm{Br} 1$ and from 1.6 to $0.5 \phi$ in profile $\mathrm{Br} 2 \mathrm{a}$. The grain-size distributions are mostly fine-skewed $\left(S_{k}\right.$ varies from -0.07 to $0.1 \phi)$ and mesokurtic or slightly leptokurtic $\left(K_{g}\right.$ commonly varies from 0.97 to $1.13 \phi$ ) in both profiles, except in lithofacies GSt, where kurtosis decreases to 0.82 , indicating a platykurtic grain size distribution. In profile $\mathrm{Br} 2 \mathrm{~b}$, the deposits of subunit $\mathrm{U} 1 \mathrm{~b}$ do not reveal as clear a fining-upwards trend in grain size composition as in the other two profiles (Fig. 6A). The grain-size distribution is much more uniform here with a domination of fine and very fine-grained sand $(69.5-78.5 \%$ and $13.8-25.0 \%$, respectively), the mean grain diameter ranging from 0.15 to $0.18 \mathrm{~mm}$, good sorting (standard deviation varies from 0.47 to $0.54 \phi)$, coarsening upwards, skewness $\left(S_{k}\right)$ decreases from 0.3 to $0.01 \phi$ with a slightly leptokurtic distribution $\left(K_{g}\right.$ varies from 1.07 to $1.2 \phi$ ).

The grain size composition of subunit U1c is dominated by fine-grained sand $(78.9 \%)$ mixed with medium and very fine-grained sand (11.0 and $8.9 \%$, respectively). The mean grain diameter is $0.18 \mathrm{~mm}$, the deposits are well sorted (standard deviation is $0.46 \phi$ ), the grain size distribution is slightly fine-skewed $\left(S_{k}\right.$ is $\left.0.09 \phi\right)$ and mesokurtic $\left(K_{g}\right.$ is $\left.1.07 \phi\right)$. Deposits of unit $\mathrm{U} 2$ in profile $\mathrm{Br} 2 \mathrm{a}$ are dominated by fine and very fine-grained sand (61.7 and $21.5 \%$, respectively) with admixture of medium-grained sand (4.9\%) and fine fractions (5.7\%). In profile $\mathrm{Br} 2 \mathrm{~b}$ they are also sand-dominated but are much coarser $(29.5 \%$ of fine-grained, $29.2 \%$ of medium-grained, $17.2 \%$ of coarse-grained, $8.6 \%$ of very fine-grained and $4.8 \%$ of very coarse-grained sand) and also include gravel (9.4\%). The mean grain diameter of these deposits is $0.15 \mathrm{~mm}$ in profile $\mathrm{Br} 2 \mathrm{a}$ and $0.33 \mathrm{~mm}$ in profile $\mathrm{Br} 2 \mathrm{~b}$. They are moderately well sorted in profile $\mathrm{Br} 2 \mathrm{a}$ (standard deviation is $0.53 \phi$ ) and poorly sorted in profile $\mathrm{Br} 2 \mathrm{~b}$ (standard deviation is $1.35 \phi$ ). The skewness and kurtosis differ between profiles: $S_{k}$ is $0.22 \phi$ and $K_{g}$ is $1.26 \phi$ in profile $\mathrm{Br} 2 \mathrm{a}$, whereas in profile $\mathrm{Br} 2 \mathrm{~b} S_{k}$ is $-0.22 \phi$ and $K_{g}$ is $1.20 \phi$ (Fig. 6A).

Quartz grain rounding in all samples analysed is characterized by a domination of sub-rounded (SR) and rounded (R) grains. In subunit U1a sub-rounded grains (47.7-61.3\%) prevail over sub-angular (5.8-27.9\%), angular (9.0-18.0\%) and rounded $(7.0-20.3 \%)$ grains. The frequency of well-rounded and very angular grains is $0.0-3.4 \%$ and $0.0-2.2 \%$, respectively. The RA index varies between 10.8 and $16.7 \%$ and the $\mathrm{Cl}$ index is from 4.6 to $17.2 \%$ (Fig. 6B). The highest values of the $\mathrm{RA}$ and $\mathrm{Cl}$ indices are characteristic of the Sh lithofacies. Subunit U1b consists of mainly sub-rounded and rounded quartz grains $(28.1-63.5 \%$ and $11.1-39.9 \%$, respectively); the frequency of sub-angular grains varies from 3.9 to $22.6 \%$ and angular grains from $5.5 \%$ to $18.2 \%$. Well rounded and very angular grains are not frequent: $0.6-6.1 \%$ and $0.0-3.2 \%$, respectively. The RA index varies between 5.5 and $18.5 \%$ and the $\mathrm{Cl}$ index is from 5.0 to $11.9 \%$ (Fig. 6B). The highest values of the $\mathrm{Cl}$ index are characteristic of the GSt and Sh lithofacies, whereas the RA index is the highest in the Sh and Sr lithofacies in profile $\mathrm{Br} 2 \mathrm{~b}$ (see Fig. 3). In subunit U1c sub-rounded grains dominate $(50.0 \%)$ over rounded and sub-angular grains (both $19.8 \%$ ). The frequency of angular grains is $8.1 \%$ and of very angular $2.3 \%$. Well rounded grains are not represented in this subunit, though this conclusion is based on the analysis of only one sample. The RA index is $10.5 \%$ and the $\mathrm{Cl}$ index is $3.5 \%$. In unit U2 two samples were analysed from two lithofacies (Dmm and GSm) and they also show also domination of sub-rounded grains (64.9 and $66.7 \%)$ over rounded (14.5 and 14.9\%), sub-angular (3.9 and 13.5\%) and angular (5.0 and 14.5\%) grains (Fig. 6B). The RA index is $5.0 \%$ (GSm) and $15.4 \%$ $(\mathrm{Dmm})$, and the $\mathrm{Cl}$ index is $7.8 \%(\mathrm{GSm})$ and $11.0 \%(\mathrm{Dmm})$.

\section{INTERPRETATION}

The grain size distribution indicates the sandy alluvial character of the unit $U 1$ deposits. Subunit U1a reveals fine and medium-grained sand-dominated, well sorted and finely skewed deposits. These features as well as the median grain size distribution are typical of transport by saltation and traction in near-bed sediment flux, characteristic of a fluvial environment (Passega, 1964; Passega and Byramjee, 1969). Subunit U1b is characterized by a fining-upwards trend reflected in the change of dominant fractions and decrease of the mean grain diameter from the bottom to the top of the subunit. These features, together with sorting increasing upwards, is consistent with the sedimentary record of erosional channels filling during flood events and changing conditions from supercritical to subcritical flows within the sand-bed braided river. The fine sand-dominated, well sorted and positively skewed deposits with horizontal bedding in the subunit unit indicate upper plane bed conditions of deposition. Unit U2 is characterized by poorer sorting with similar contents of fine, medium and coarse-grained sand as well as admixtures of gravel and fine fractions, characteristic 


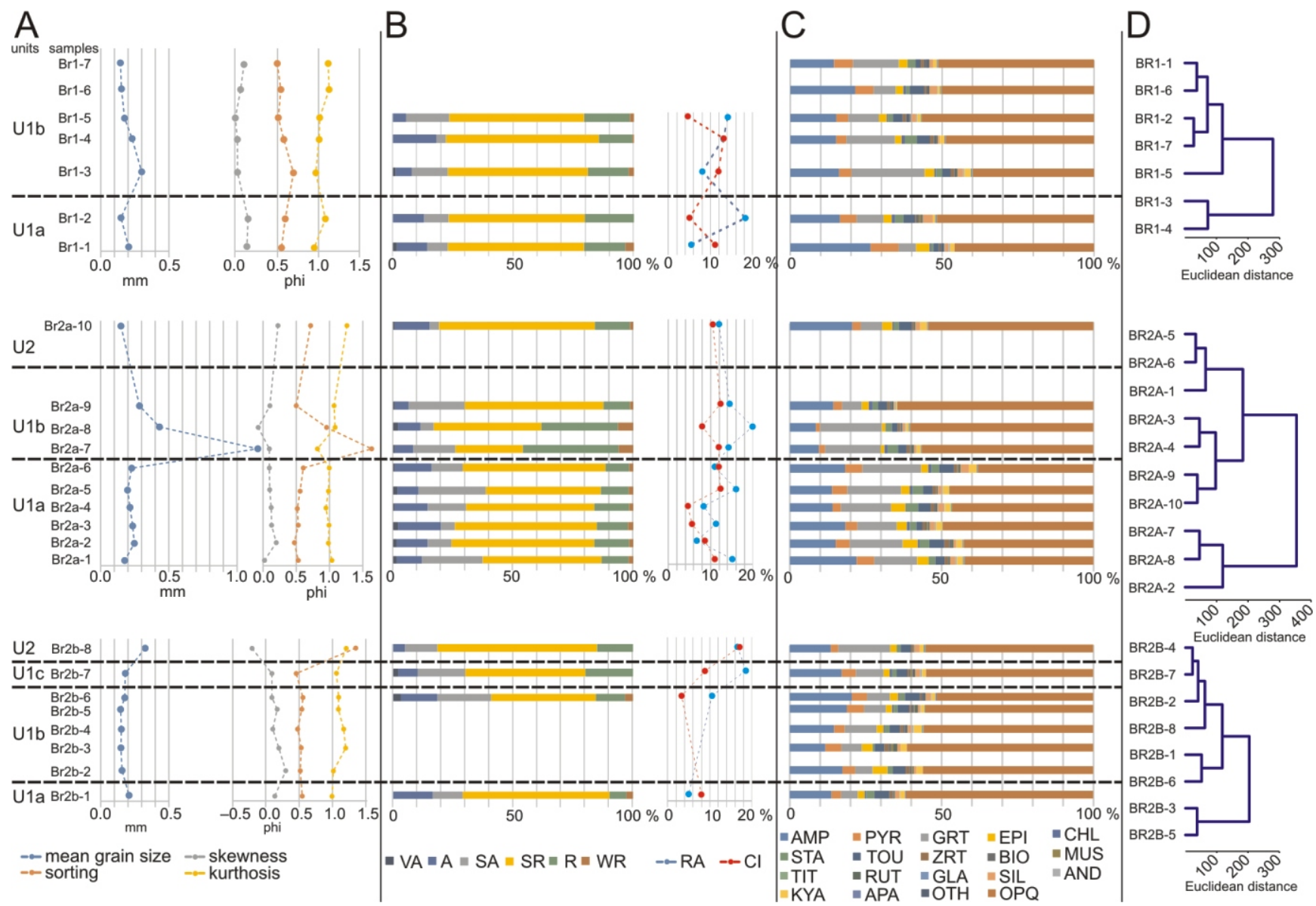

Fig. 6. Results of laboratory analyses

A - grain size parameters; $\mathbf{B}$ - quartz grain rounding; C - heavy minerals assemblage; $\mathbf{D}$ - cluster analysis of heavy minerals

of gravity flow deposits, most likely solifluction as coarser grains were transported down a gentle slope along the top surface of the fluvial succession (Schwan et al., 1982).

Fluvial sediments usually contain grains of relatively mature, rounded grains. The domination of sub-rounded and rounded quartz grains in unit U1 and mostly good sorting of these deposits indicate relatively long transport and effective fluvial processes transforming grains. Significant amounts of sub-angular and angular grains in some samples may indicate supply of grains from previously deposited braided river or fluvioglacial deposits in the frozen river banks. This is consistent with the occurrence of angular clasts of sand with preserved internal structure within lithofacies of the $\mathrm{U} 1 \mathrm{~b}$ subunit.

\section{HEAVY MINERALS}

DESCRIPTION

The heavy mineral assemblage (Fig. 6C) is dominated by opaque minerals, averaging $52 \%$ of the content. Transparent heavy mineral spectra consist mainly of amphiboles and garnets with average contents of 16.3 and $12.3 \%$, respectively. Other minerals which share $>1 \%$ of the assemblage are: pyroxenes $(4.4 \%)$, tourmaline $(3.5 \%)$, staurolite $(2.2 \%)$, kyanite $(1.6 \%)$, and sillimanite (1.5\%). Minerals identified in each sample include: amphiboles, pyroxenes, garnets, epidotes, staurolite, tourmaline, zircon, rutile, sillimanite, and kyanite. Each profile has a similar distribution of heavy mineral spectra.
Lithofacies of Unit 1 show a relatively increased content of garnets and zircons in the cross stratified sands, which decreases up the channel in-fill. Sandy lithofacies related to ripple cross-lamination and horizontally stratified sands show a relatively increased content of opaque minerals, amphiboles and pyroxenes. Cluster analysis (Fig. 6D) shows dissimilarity between the cross-stratified sandy gravel lithofacies together with the lower parts of the horizontally stratified sands, to other lithofacies identified in each profile. Unit 2 comprising diamicton does not reveal notable differences in heavy mineral assemblage from the sandy lithofacies showing a relatively increased content of amphiboles, pyroxenes, and opaque minerals. This was also revealed by cluster analysis (Fig. 6D) where samples $\mathrm{Br} 2 \mathrm{a}-10$ and $\mathrm{Br} 2 \mathrm{~b}-8$ taken from the diamicton share the same 2nd order cluster as the Sr and (mainly) Sh lithofacies.

\section{INTERPRETATION}

The heavy mineral assemblage in the fluvial deposits of Unit 1 shows a relation to flow conditions. Samples taken from the GSt, SGt, and the lower part of the Sh lithofacies group into different clusters (Fig. 6D) than do the samples taken from other parts of the profiles. The difference appears in a higher content of transparent minerals, including those of higher density (mainly garnets and zircon) in the trough cross-stratified gravels and sands. The channel infill also indicates a vertical and lateral shift of heavy mineral assemblage towards a composition with relatively increased contents of amphiboles and 
Results of OSL dating

\begin{tabular}{|c|c|c|c|c|c|c|c|}
\hline Lab.code & Sample ID & Th (Bq/kg) & $\mathrm{U}(\mathrm{Bq} / \mathrm{kg})$ & $\mathrm{K}(\mathrm{Bq} / \mathrm{kg})$ & $\begin{array}{c}\text { Dose rate } \\
\text { [Gy/ka] }\end{array}$ & $\begin{array}{c}\text { Equivalent } \\
\text { dose [Gy] }\end{array}$ & OSL age [ka] \\
\hline GdTL-2519 & $\mathrm{Br} 11$ & $6.7 \pm 0.3$ & $3.6 \pm 0.3$ & $272 \pm 8$ & $1.08 \pm 0.04$ & $75.8 \pm 2.8$ & $70.3 \pm 3.7$ \\
\hline GdTL-2520 & $\mathrm{Br} 2$ & $11.8 \pm 0.4$ & $9.0 \pm 0.5$ & $332 \pm 10$ & $1.43 \pm 0.05$ & $82.0 \pm 5.4$ & $57.4 \pm 4.3$ \\
\hline GdTL-2521 & $\mathrm{Br} 3$ & $7.1 \pm 0.2$ & $5.2 \pm 0.3$ & $200 \pm 6$ & $0.92 \pm 0.03$ & $66.9 \pm 2.8$ & $72.9 \pm 4.0$ \\
\hline GdTL-2522 & $\mathrm{Br} 4$ & $7.2 \pm 0.2$ & $5.1 \pm 0.2$ & $227 \pm 6$ & $1.00 \pm 0.04$ & $68.5 \pm 3.5$ & $68.4 \pm 4.2$ \\
\hline GdTL-2523 & $\mathrm{Br} 5$ & $7.3 \pm 0.6$ & $5.3 \pm 0.5$ & $247 \pm 8$ & $1.07 \pm 0.04$ & $71.0 \pm 3.2$ & $66.4 \pm 3.9$ \\
\hline GdTL-2524 & $\mathrm{Br} 6$ & $11.3 \pm 0.5$ & $8.1 \pm 0.6$ & $300 \pm 9$ & $1.34 \pm 0.05$ & $81.1 \pm 4.9$ & $60.6 \pm 4.2$ \\
\hline GdTL-2525 & $\mathrm{Br} 7$ & $10.8 \pm 0.3$ & $7.4 \pm 0.4$ & $306 \pm 8$ & $1.35 \pm 0.05$ & $84.9 \pm 3.5$ & $63.0 \pm 3.4$ \\
\hline
\end{tabular}

Equivalent doses and ages obtained based on the CAM model

pyroxenes, which are less likely to be transported and preserved where currents are swift. Thus, the hydrodynamic conditions of the former braided river played an important role in selective distribution of the heavy minerals. In Unit U2 composed of diamicton, the heavy minerals show the same composition as do the fluvial deposits, which probably indicate the same source of sediment: older, glacial/interglacial cycle Pleistocene deposits.

\section{OSL DATING}

DESCRIPTION

Seven samples of sand deposits from profile $\mathrm{Br} 1$ were dated by OSL: two from the SI and Sh lithofacies in subunit U1a and five from the St, Sh and Sr lithofacies in subunit U1b (Figs. 3 and 7). OSL ages of these deposits are consistent and range from $72.9 \pm 4.0 \mathrm{ka}$ to $57.4 \pm 4.3 \mathrm{ka}$ (Table 1 and Fig. 7 ). Ages obtained from subunits U1a and U1b overlap within the ranges of uncertainty. Overdispersion parameters change from 17 to $32 \%$, which is reflected in the age distribution for the samples investigated. For four samples (samples $\mathrm{Br} \_1, \mathrm{Br} \_3, \mathrm{Br} \_$, $\mathrm{Br} 7$ ) the distributions have a unimodal character (overdispersion is $<20 \%$ ), in contrast to the samples with polymodal character (samples $\mathrm{Br} \_2, \mathrm{Br} \_4, \mathrm{Br} \_6$ ).

INTERPRETATION

Besides the imperfection of the age distributions, the OSL data obtained is relatively consistent, pointing to MIS 4 as the time of fluvial sequence deposition. Based on a large number of ages (7), we can determine the most probable age for unit U1. Using the CAM model for all aliquots, the distribution obtained is almost unimodal (Fig. 8) and the final result is $65.2 \pm 1.5 \mathrm{ka}$. This means that this unit was deposited during MIS 4, broadly accepted as one of the cold stages of the last glacial (Railsback et al., 2015).

\section{DISCUSSION}

Studies of the deposits at the Brześnica site indicated several problems related to sedimentological and stratigraphical interpretations. These comprise: the palaeoenvironmental setting and inferred sedimentary features; the age of the deposits documented and the new perspective they provide on accumulation and erosion phases during the middle part of the last glacial and on the time span of braided river sedimentation; and upstream fluvial sedimentation under cold continental condi- tions during MIS 3 and MIS 4 and its relation to downstream fluvial pattern evolution at the same time. Our findings may be compared to related research results from from Poland and NW Europe.

\section{SEDIMENTARY ENVIRONMENTS}

The silts and clays recognized within fluvial unit $\mathrm{U} 1$ did not yield sufficient data to allow precise interpretation. They may have formed in an overbank fluvial subenvironment or in an extensive, cold based lake (Zieliński, 2017). The sandy deposits recognized in Unit 1 in the Brześnica site formed in a fluvial environment associated with cold climate conditions. Lithofacies assemblages within Unit U1 overall indicate the existence of a shallow braided river environment with rapid ephemeral sheetfloods. The main sediment transport and deposition probably took place during the warmer parts of the year (cf. Petera, 2002).

Palaeocurrent measurements differ between the bottom part of the fluvial unit and the channel infills in the upper parts of the interchannel bars. In the former, an ESE direction reflects the primary direction of the palaeoflow of the fluvial succession at the Brześnica site, while the eastern direction obtained from the trough cross-stratified deposits is associated with a particular preserved channel. The consistent directions are in this case circumstantial. Palaeoflow directions from shallow depositional bedforms are related to various flood events during which the interchannel bars were completely submerged. Because of that, the mean vector obtained from the ripple cross-laminated strata is a reliable direction of general palaeoflow in the river valley at the time of fluvial unit U1 deposition. The 0.5-1 m thickness of tabular strata (lithofacies SGt, St) indicates a flow depth of $\sim 1-3 \mathrm{~m}$ in the central part of the channel (Bridge, 2003).

Sharp-edged sandy intraclasts and SSDS linked to a periglacial environment and ice-wedges point to cold climate conditions throughout deposition of the fluvial strata, and also continuation of these conditions after the end of fluvial deposition (van Huissteden and Kasse, 2001). The former cold open landscape should have resulted in increased aeolian activity and a dominant supply of rounded and subrounded grains (Woronko et al., 2015). However, many samples from Brześnica revealed a higher (up to $30 \%$ ) content of sub-angular and angular quartz grains. These may have been supplied by erosion of the frozen river banks of the braided fluvial system and/or by incorporation of older fluvioglacial and glacial sediments in the catchment area. The average composition of the heavy mineral spectrum in samples from the Brześnica site is similar to other nearby sites described by e.g., Czerwonka and Krzyszkowski (1994) and Krzyszkowski et al. (1999). Addition- 

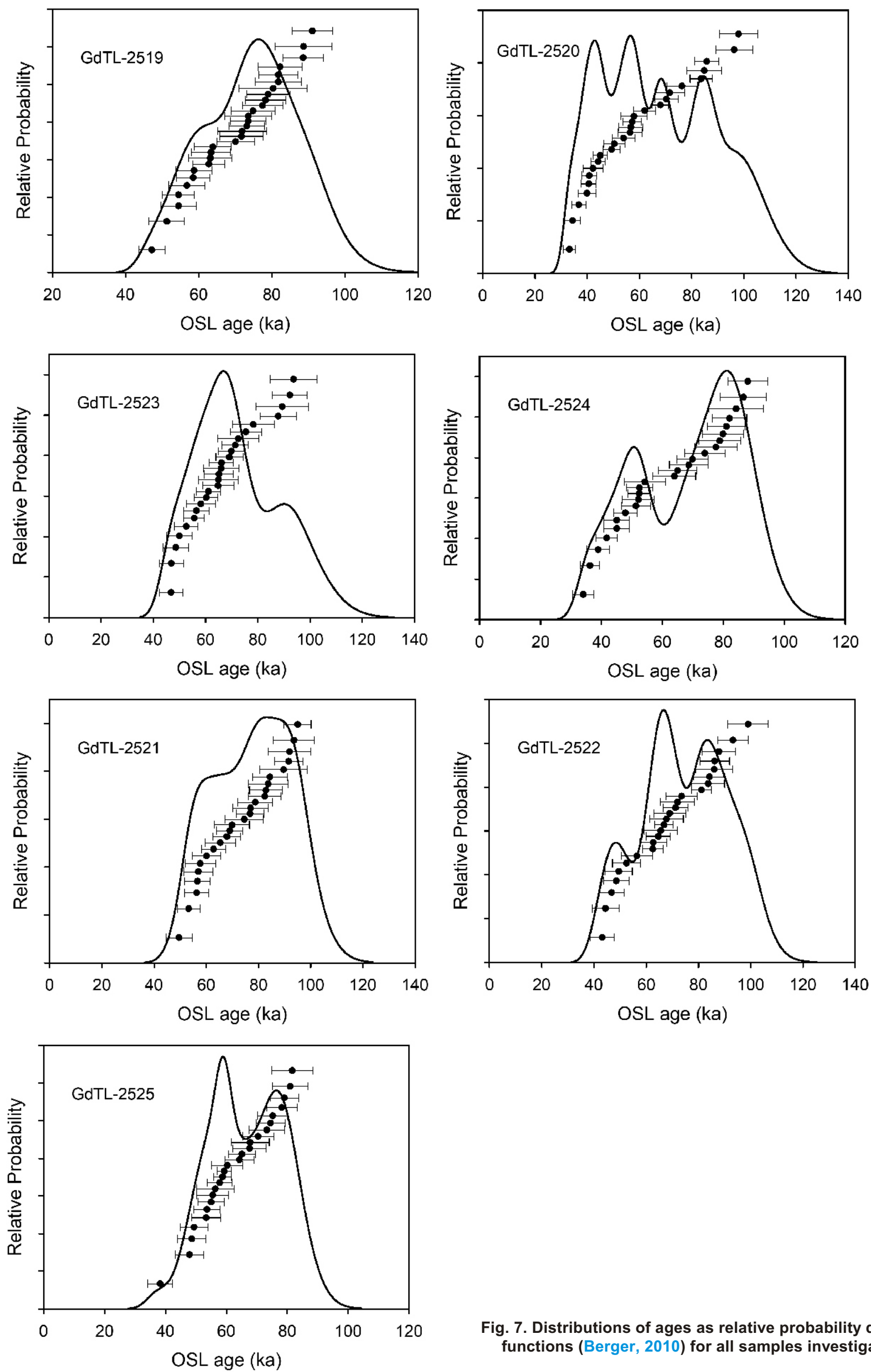

Fig. 7. Distributions of ages as relative probability density functions (Berger, 2010) for all samples investigated 


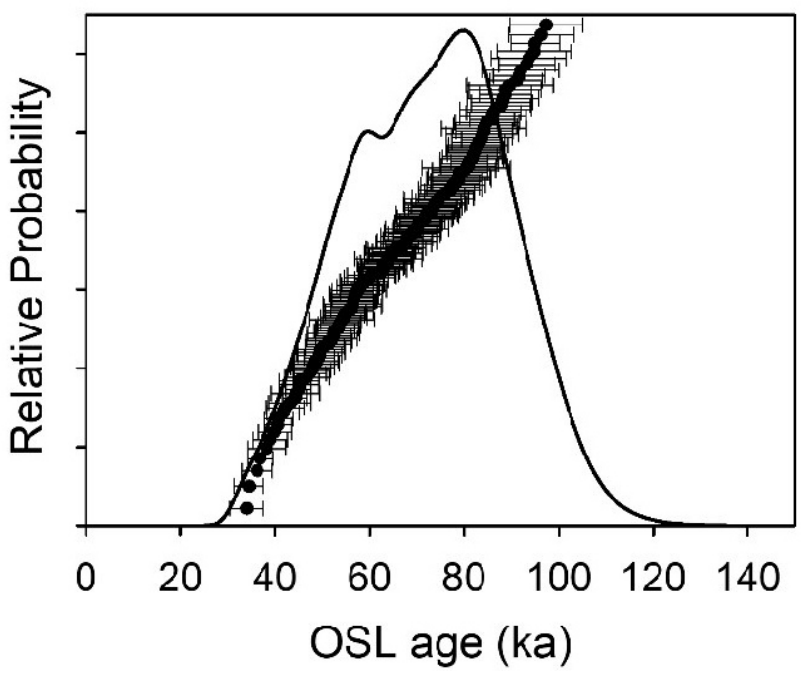

Fig. 8. Distributions of all measured aliquots for all samples from the Brześnica site as relative probability density function (Berger, 2010)

ally, similar heavy mineral assemblage in Unit 1 and 2 indicate a uniform provenance. Considering the regional palaeogeography, the source would be reworked Quaternary glacial or/and fluvioglacial deposits with some incorporation of older, Miocene and Pliocene fluvial deposits (cf. Czerwonka and Krzyszkowski, 1994). Rafts of Miocene deposits are common in the region, including those at the surface close to Dolsk (see area 16 in Fig. 2). Both textural and mineral features recognized at Brześnica point to a relatively stable and mature braided river environment which developed in specific, cold climate conditions within an area associated with glaciation events.

\section{GEOCHRONOLOGY AND PALAEOGEOGRAPHY}

Silts and clays were found beneath the fluvial unit at the bottom of the exploration pit. Considering the local stratigraphy, they may have been deposited during the Early Glacial or when the Early Glacial gave way to the Pleniglacial of Weichselian Glaciation (MIS 5a-4; cf. Peeters et al., 2016). The Eemian Interglacial (MIS 5e) was dominated by low energy river systems and relatively high accumulation rate of organic matter (Sokołowski et al., 2014; Dzieduszyńska et al., 2020). The Early Glacial (MIS 5a) is known to have been a time of rapid climate change, which strongly influenced river catchment area and may have resulted e.g., in erosion of the upper part of previously deposited sediments of that age. Additionally, cooler climate conditions led to stepwise vegetation change leading to open steppe (Żarski et al., 2018). The accompanying base level fall boosted widespread erosion and resulted in a reduction of sedimentary profiles. Krzyszkowski and Kuszell (2007) reported the presence of laminated silts above the Saalian (MIS 6) deposits, dated with ${ }^{14} \mathrm{C}$ to MIS 3 , and perhaps formed in slow-water conditions on a fluvial floodplain. These deposits preceded the subsequent erosional phase and the change of fluvial sedimentation style to a faster-flowing braided system pattern. Similar changes has also been reported from other sites in deposits of various ages (e.g., Jańczak, 1981; Rotnicki, 1987; Dzieduszyńska et al., 2020). This type of sedimentary and stratigraphical transition may be typical of fluvial sedimentation style changes during the last glacial in the continental part of the European river system. This suggests that the silts and clays which underlie the fluvial deposits at Brześnica and their upper erosional boundary may be related to the Early Glacial (MIS 5a-d).

OSL dating showed that the fluvial sequence was deposited between $\sim 53$ to $77 \mathrm{ka}$ in MIS 4, with a most probable average age of $65.2 \pm 1.5 \mathrm{ka}$ (Table 1; Figs. 7 and 8 ). However, this result may be slightly overestimated. 5 out of 7 samples were collected from the channel infill and sample $\mathrm{Br}$ _2 showed a clearly polymodal age distribution. Considering the age distributions (Fig. 7), accumulation within channel bedforms may lead to incomplete bleaching (cf. Weckwerth et al., 2013). All in all, we conclude that fluvial deposition recorded at Brześnica took place during MIS 4, which is also supported by the succession representing a braided river environment, probably related to cold climate conditions. The ages obtained for the fluvial deposits cover a time span usually interpreted in this region to be the main erosional phase of the early Weichselian (MIS 5a-d; e.g., Krzyszkowski, 1990; Czerwonka and Krzyszkowski, 1994; Krzyszkowski and Kuszell, 2007). We are not able to completely exclude that fluvial deposition continued up to MIS 3 , the OSL dating results provide sufficient data for our interpretation. In this case, the age difference between the deposits recognized at Brześnica and those described at other sites in central Poland (cf. e.g., Krzyszkowski and Kuszell, 2007; Zieliński et al., 2019) would exceed $30 \mathrm{ky}$ at the time of fluvial sedimentation. We suggest that the main erosional phase took place during early MIS 3, after the deposition of braided fluvial deposits in MIS 4. This interpretation also fits the recent scheme obtained in the area close to the ice-sheet limit during the LGM in central Poland (Dzieduszyńska et al., 2020).

Krzyszkowski and Gratzke (1994) described several exposures along the Leszno Phase margin. They found, beneath the tills of the last glaciation, sandy and gravelly deposits and related them to a river or Gilbert-type delta. Typically, sedimentary sequences recognized there are dominated by $\mathrm{St}$, Sh and $\mathrm{Sr}$ lithofacies or coarse planar or horizontally stratified deposits, respectively. In the upper part of fluvial sequence, ice-wedges were also observed. Those authors interpreted the fluvial deposits to be a record of a braided river environment with ephermal sheetfloods, in proximal position to the margin of the ice-sheet (e.g., the Osieczna site located close to Leszno, Fig. 1). The basic stratigraphical position of this fluvial sequence is consistent with our findings, as the general features of the sedimentary successions are very similar. Some of the previously described fluvial archives could, like this one, be supported with dating and enhance knowledge of fluvial palaeogeography and erosional/accumulational phases since the Eemian.

Marks et al. (2016) noted aeolian activity, ice-wedge formation, involutions and solifluction as typical signatures of cold MIS 4 and cold phases of MIS 3 in Poland. These observations support our chronology of processes interpreted at Brześnica (Fig. 9A), as after braided river sedimentation in MIS 4, ice wedges, SSDS, and slope deposits linked to solifluction were recognized and can be related to the period of late MIS 4 to early MIS 3 . It is also possible that ice wedge formation and solifluction of the diamictic deposits occurred later, during MIS 2. The sedimentary sequence analysed shows that the upper part of the fluvial deposits was eroded, which may be a signature of warmer periods of MIS 3 and related wide-scale erosion. However, the eroded upper part of the ice-wedge cast documented (Fig. 4E) suggests earlier formation of periglacial structures. Thus, erosion must have occurred after cold stage MIS 4 and before the ice-sheet advance in MIS 2. Similar observations were reported by Zieliński et al. (2019), who recognized, in eastern Poland, deposits of a sandy braided river with associ- 


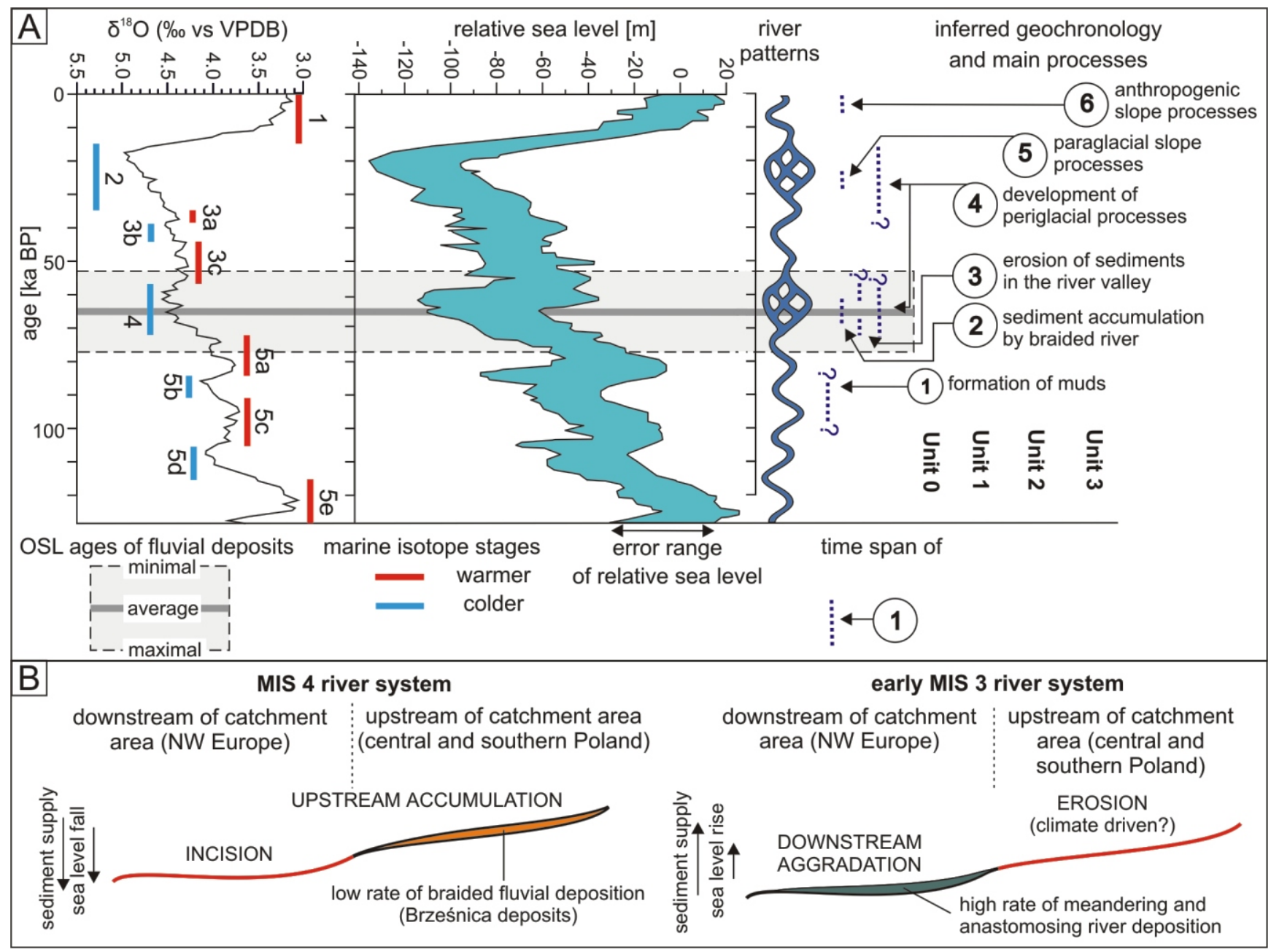

Fig. 9. Summary of the evolution of the sedimentary sequence at Brześnica showing relationships between depositional environment, climate and sea level changes

A - timespan of fluvial deposition and other geological processes recognized at Brześnica compared to $\delta^{18} \mathrm{O}$ and relative sea level changes, $\delta^{18} \mathrm{O}$ marine isotope changes after Railsback et al. (2015), sea level curve after Röhling et al. ( 2012), both modified and smoothed; B - fluvial response for environmental changes related to the river/catchment long profile during MIS 4 and early MIS 3 , the upstream catchment area responded with a lag to climate and relative sea level changes in comparison to the downstream part of the fluvial system

ated permafrost features of MIS 4 age, followed by a stratigraphic gap covering all of MIS 3. Braided river deposits were also found by Petera (2002) in the Uniejów Basin. In this case, the bottom part of the fluvial unit formed in MIS 4 showed features indicating erosion of previously accumulated deposits. During MIS 4, parallel to the braided river environment, permafrost also developed and left characteristic accompanying sedimentary features. The braided river functioned in an arctic or subarctic regime with probably ephemeral (mostly summer) flow dominated by bedload transport of sediments.

\section{FLUVIAL SYSTEMS DURING MIS 4 AND MIS 3}

Deposition of analysed braided fluvial sequence during MIS 4, $\sim 65.2 \pm 1.5$ ka corresponds to the evolution of European palaeofluvial systems during the Late Pleistocene (e.g., Mol et al., 2000; van Huissteden et al., 2001; Zieliński et. al., 2019; Dzieduszyńska et al., 2020). River systems in central Europe were prone to sea level changes and ice-sheet advances (Starkel, 1997; Marks, 2004; Moskalewicz et al., 2016). Subsequent warm and cold periods during MIS 5-2 controlled the flu- vial pattern and river flow parameters (Marks et al., 2016). During interglacials, the Baltic basin was periodically or constantly connected to the global ocean through the Danish Straits or White Sea (Miettinen et al., 2014). However, during cold periods, the Baltic basin was usually occupied by an ice sheet, also during MIS 4 (Svendsen, 2004; Batchelor et al., 2019), which means that the base of the river system studied was shifted far to the west and continental climate conditions intensified due to isolation from the global ocean. The climate in Poland during MIS 4 was characterized by strong continental conditions, temperature decrease and vegetation cover change, from forest to open vegetation communities (Henriksen et al., 2008; Holm and Svenning, 2014; Roman et al., 2014; Malkiewicz, 2018). Hence, a shift from a meandering sedimentation style to a braided one is expected.

During MIS 4 widespread river incision took place in western and central Europe, though being much more pronounced on the west (van Huissteden et al., 2001). During this phase, a braided river sedimentation style was dominant. In the context of sea level changes during the last glacial-interglacial cycle, fluvial system evolution in NW Europe may be clearly linked to a 
sequence stratigraphy framework (Catuneanu, 2002, 2006), in which the sedimentary record from MIS $5 d-3$ was related to a falling-stage systems tract (Peeters et al., 2018). At the Brześnica site, which is representative for the upstream part of the catchment area, MIS 4 was marked by a sandy braided-river sedimentation style, and erosion took place later, probably mainly during early MIS 3 (Fig. 9B). This may indicate delayed subaerial erosion (incision) due to a much longer distance to base level, higher altitudes of sedimentation and sufficient sediment supply.

During MIS 3, river valleys in the western Europe were already filled with fine sediments and low energy river patterns (meandering and anastomosing) developed, which gave way to glaciation of MIS 2 and a change to widespread braided river systems (van Huissteden et al., 2001; Peeters et al., 2016). These younger deposits were usually marked by an erosional bottom boundary. This is consistent with following sequence stratigraphy phase during which downstream parts of river systems start to aggrade under stabilization of base level (Catuneanu, 2002, 2006). The continental part of the catchment area was subjected to erosion at that time, indicated by a delay of fluvial response to base level changes. Fluvial aggradation in MIS 4 and incision in early MIS 3 has been reported also from other areas in the central-eastern Europe (Starkel et al., 2015; Panin et al., 2017). This phase did not last long because the sedimentary record of fluvial deposits from MIS 3-2 has been found at many sites (e.g., Roman et al, 2014; Zieliński et al., 2015; Panin et al., 2017).

Fluvial deposition and related incision in MIS 4-3 in Poland may have been controlled not only by direct climate change influencing the river catchment area but to some degree also by relative sea level changes which were demonstrated in the downstream and upstream evolution of fluvial sedimentary record over time. Some researchers argue that involving sea level changes in fluvial system evolution is often overestimated as the amount of data is too limited and many factors may influence river catchment area (e.g., Miall, 2015). It is not clear how strong an impact base level changes had on fluvial sedimentary record in central and southern Poland, if any. For sure, it was less pronounced than in the western Europe and climate change could have been more important at that time in a continental setting. In consequence, during MIS 4, braided fluvial patterns could evolve and mark their presence in the sedimentary record. Sites located in central and southern Poland developed in upstream parts of the river catchment area and were probably too far to the then shoreline to be notably influenced by sea level changes as in NW Europe (Peeters et al., 2018); however, delay and noticeable fluvial response to base level changes with strong climate dependence may be reliably inferred (Fig. 9B). The contrast between the downstream and upstream parts of fluvial systems in central Europe during MIS 4-3 as well as aggradation-accumulation phases may be a notable, recurring feature of the Pleistocene fluvial sedimentary record, which appear when environmental conditions reach specific levels. However, this point of view requires more study to establish whether it is a general concept.

\section{CONCLUSIONS}

1. The sedimentary record at the Brześnica site is interpreted as the result of accumulation in a braided fluvial environment during cold MIS 4 at $65.2 \pm 1.5 \mathrm{ka}$. After deposition, the main erosional phase occurred in the river valley during early MIS 3 and resulted in curtailing of sedimentary profiles. Subsequent climate change and a shift to near-glacial conditions led to development of permafrost features and paraglacial slope processes.

2. The slope of the river valley was an important control of deposition in subsequent phases of accumulation. This was expressed in the palaeocurrent data, the inclined bottom surface of fluvial sequence consistent with palaeocurrents, the deformation structures in the upper part of the fluvial deposits, and the lateral shift of sedimentary features in the diamictic cover.

3. The timing of fluvial accumulation and erosion phases fits the framework of a fluvial response to climate and sea level changes during MIS 5-2, though the sedimentary record does not show this as clearly as in the downstream part of the catchment area. The upstream part of the river system revealed a delayed influence of environmental and sea level changes but also showed the dominant role of climate.

4. The contrast between the downstream and upstream parts of fluvial systems, including factors influencing sedimentation style, in central Europe during MIS 4-3 might represent a general pattern for the Pleistocene fluvial sedimentary record. This potential relationship requires more studies of Pleistocene fluvial deposits from the European Lowlands to place it in a broader context.

Acknowledgements. We thank two anonymous reviewers for their careful reading of our manuscript and their many insightful comments and suggestions, which improved the manuscript. The study was financially supported by the Polish National Science Centre (NCN grant no. 2014/15/D/ST10/04113), Departments of Geomorphology and Quaternary Geology and Marine Geology, at the University of Gdańsk.

\section{REFERENCES}

Aitken, M.J., 1998. An Introduction to Optical Dating. Oxford University Press, Oxford.

Ashley, G.M., 1990. Classification of large-scale subaqueous bedforms: a new look at an old problem. Journal of Sedimentary Petrology, 60: 160-172.

Batchelor, C.L., Margold, M., Krapp, M., Murton, D.K., Dalton, A.S., Gibbard, P.L., Stokes, C.R., Murton, J.B., Manica, A. 2019. The configuration of Northern Hemisphere ice sheets through the Quaternary. Nature Communications, 10: 3713.

Berger, G.W., 2010. An alternate form of probability - distribution plot for De values. Antient TL, 28: 11-22.
Blazauskas, N., Jurgaitis, A., Sinkunas, P., 2007. Patterns of Late Pleistocene proglacial fluvial sedimentation in the SE Lithuanian Plain. Sedimentary Geology, 193: 193-201.

Blott, S.J., Pye, K., 2001. GRADISTAT: a grain size distribution and statistics package for the analysis of unconsolidated sediments. Earth Surface Processes and Landforms, 26: 1237-1248.

Blum, M.D., Törnqvist, T.E., 2000. Fluvial response to climate and sea-level change: a review and look forward. Sedimentology, 47: 2-48.

Bridge, J.S., 2003. Rivers and Floodplains: Forms, Processes, and Sedimentary Record. Blackwell, Oxford. 
Bridge, J.S., Demicco, R.V., 2008. Earth Surface Processes, Landforms and Sediment Deposits. Cambridge University Press, New York.

Busschers, F.S., Van Balen, R.T., Cohen, K.M., Kasse, C. Weerts, H.J.T., Wallinga, J., Bunnik, F.P.M., 2008. Response of the Rhine-Meuse fluvial system to Saalian ice-sheet dynamics. Boreas, 37: 377-398.

Catuneanu, O., 2002. Sequence stratigraphy of clastic systems concepts, merits, and pitfalls. Journal of African Earth Sciences, 35: $1-43$.

Catuneanu, O., 2006. Principles of Sequence Stratigraphy Elsevier, Amsterdam.

Colombera, L., Mountney, N.P., 2019. The lithofacies organization of fluvial channel deposits: a meta-analysis of modern rivers. Sedimentary Geology, 383: 16-40.

Czerwonka, J.A., Krzyszkowski, D., 1994. Pleistocene stratigraphy and till petrography of the central Great Poland Lowland western Poland. Folia Quaternaria, 65: 7-71.

Dzieduszyńska., D., Petera-Zganiacz, J., Roman, M., 2020. Vistulian periglacial and glacial environments in central Poland: an overview. Geological Quarterly, 64 (1): 54-73.

Eissmann, L., 2002. Quaternary geology of eastern Germany (Saxony, Saxon-Anhalt, South Brandenburg, Thuringia), type area of the Elsterian and Saalian Stages in Europe. Quaternary Science Reviews, 21: 1275-1346.

Folk, R.L., Ward, W.C., 1957. Brazos River bar: a study in the significance of grain size parameters. Journal of Sedimentary Petrology, 27: 3-26.

Galbraith, R.F., Roberts, R.G., Laslett, G.M., Yoshida, H., Olley, J.M., 1999. Optical dating of single and multiple grains of quartz from Jinminum Rock Shelter, Northern Australia. Part I, experimental design and statistical models. Archaeometry, 41 1835-1857.

Guerin, G., Mercier, N., Adamiec, G., 2011. Dose-rate conversion factors: update. Ancient TL, 29: 5-8.

Haughton, P., Davis, Ch., McCaffrey, W., Barker, S., 2009. Hybrid sediment gravity flow deposits - classification, origin and significance. Marine and Petroleum Geology, 26: 1900-1918.

Hays, J.D., Imbrie, J., Shackleton, N.J., 1976. Variations in the Earth's orbit: pacemaker of the Ice Ages. Science, 194: 1121-1132.

Henriksen, M., Mangerud, J., Matiouchkov, A., Murray, A.S., Paus, A., Svendsen, J.I., 2008. Intriguing climatic shifts in a 90 kyr old lake record from northern Russia. Boreas, 37: 20-37.

Holm, S.R., Svenning, J.-C., 2014. 180,000 years of climate change in Europe: Avifaunal responses and vegetation implications. PLoS ONE 9: e94021.

Houben, P., 2003. Spatio-temporally variable response of fluvial systems to Late Pleistocene climate change: a case study from central Germany. Quaternary Science Reviews, 22: 2125-2140.

Huisink, M., 1997. Late-glacial sedimentological and morphological changes in a lowland river in response to climatic change: the Maas, southern Netherlands. Journal of Quaternary Science, 12: 209-223.

Jańczak, J., 1981. Rozwój dolin Wysoczyzny Jarocińskiej podczas młodszego czwartorzędu (in Polish). Badania fizjograficzne nad Polską Zachodnią, 34: 70-98.

Kenzler, M., Tsukamoto, S., Meng, S., Thiel, C., Frechen, M. Hüneke, H., 2015. Luminescence dating of Weichselian interstadial sediments from the German Baltic Sea coast. Quaternary Geochronology, 30: 251-256.

Krzyszkowski, D., 1990. Middle and Late Weichselian stratigraphy and palaeoenvironments in central Poland. Boreas, 19: 333-350.

Krzyszkowski, D., Gratzke, B., 1994. History of glaciation in the zone of maximum extent of the Late Weichselian ice-sheet near Leszno, western Poland. Folia Quaternaria, 65: 143-194.

Krzyszkowski, D., Kuszell, T., 2007. Middle and Upper Weichselian Pleniglacial fluvial erosion and sedimentation phases in Southwestern Poland, and their relationship to Scandinavian ice sheet build-up and retreat. Annales Societatis Geologorum Poloniae, 77: 17-38.
Krzyszkowski, D., Gizler, H., Jodłowski, J., Dobosz, T., 1999. Quaternary geology and geomorphology in the zone of the maximum extent of the Weichselian ice sheet between Sława Śląska and Święciechowa, western Poland. Quaternary Studies in Poland, 16: 47-66.

Leigh, D.S., 2006. Terminal Pleistocene braided to meandering transition in rivers of the Southeastern USA. Catena, 66: 155-160.

Macklin, M.G., Lewin, J., Woodward, J.C., 2012. The fluvial record of climate change. Philosophical Transactions of the Royal Society A, 370: 2143-2172.

Malkiewicz, M., 2018. A Late Saalian Glaciation, Eemian Interglacial and Early Weichselian pollen sequence at Szklarka, SW Poland - reconstruction of vegetation and climate. Quaternary International, 467: 43-53.

Mange, M.A. and Maurer, H.F.W., 1992. Heavy Minerals in Colour. Chapman \& Hall, London.

Marks, L., 2004. Middle and Late Pleistocene fluvial systems in central Poland. Proceedings of the Geologists' Association, 115: 175-182

Marks, L., Gałązka, D., Woronko, B., 2016. Climate, environment and stratigraphy of the last Pleistocene glacial stage in Poland. Quaternary International, 420: 259-271.

Miall, A., 1996. The Geology of Fluvial Deposits. Sedimentary Facies, Basin Analysis, and Petroleum Geology. Springer, New York.

Miall, A., 2015. Updating uniformitarianism: stratigraphy as just a set of 'frozen accidents'. Geological Society Special Publications, 404: 11-36.

Miettinen, A., Head, M.J., Knudsen, K.L., 2014. Eemian sea-level highstand in the eastern Baltic Sea linked to long-duration White Sea connection. Quaternary Science Reviews, 86: 158-174.

Mol, J., Vandenberghe, J., Kasse, C., 2000. River response to variations of periglacial climate in mid-latitude Europe. Geomorphology, 33: 131-148.

Moskalewicz, D., Sokołowski, R.J., Fedorowicz, S., 2016. River response to climate and sea level changes during the Late Saalian/Early Eemian in northern Poland - a case study of meandering river deposits in the Chłapowo cliff section. Geologos, 22: 1-14.

Murray, A.S., Wintle, A.G., 2000. Luminescence dating of quartz using an improved single aliquot regenerative-dose protocol. Radiation Measurements, 32: 57-73.

Olsen, L., 1983. A method for determining total clast roundness in sediments. Boreas, 12: 17-21.

Owen, G., Moretti, M., 2008. Determining of the origin of soft-sediment deformation structures: a case study from Upper Carboniferous delta deposits in south-west Wales, UK. Terra Nova, 20: $237-245$.

Panin, A., Adamiec, G., Buylaert, J.P., Matlakhova, E., Moska, P., Novenko, E., 2017. Two Late Pleistocene climate-driven incision/aggradation rhythms in the middle Dnieper River basin, west-central Russian Plain. Quaternary Science Reviews, 166: 266-288.

Passega, R., 1964. Grain size representation by CM patterns as a geological tool. Journal of Sedimentary Petrology, 34: 830-847.

Passega, R., Byramjee, R., 1969. Grain-size image of clastic deposits. Sedimentology, 13: 233-252.

Peeters, J., Busschers, F.S., Stouthamer, E., Bosch, J.H.A., Van den Berg, M.W., Wallinga, J., Versendaal, A.J., Bunnik, F.P.M., Middelkoop, H., 2016. Sedimentary architecture and chronostratigraphy of a late Quaternary incised-valley fill: A case study of the late Middle and Late Pleistocene Rhine system in the Netherlands. Quaternary Science Reviews, 131: 211-236.

Peeters, J., Cohen, K.M., Thrana, C., Busschers, F.S., Martinius, A.W., Stouthamer, E., Middelkoop, H., 2018. Preservation of Last Interglacial and Holocene transgressive systems tracts in the Netherlands and its applicability as a North Sea Basin reservoir analogue. Earth-Science Reviews, 188: 482-497. 
Petera, J., 2002. Vistulian valley deposits in the Uniejów Basin and their palaeogeographical significance (in Polish with English summary). Acta Geographica Lodzensia, 83: 1-164.

Powers, M.C., 1953. A new roundness scale for sedimentary particles. Journal of Sedimentary Research, 23: 117-119.

Prescott, J.R., Stephan, L.G., 1982. The contribution of cosmic radiation to the environmental dose for thermoluminescence dating. Latitude, altitude and depth dependencies. TLS II-1, 16-25.

Railsback, L.B., Gibbard, P.L., Head, M.J., Voarintsoa, N.R.G., Toucanne, S., 2015. An optimized scheme of lettered marine isotope substages for the last 1.0 million years, and the climatostratigraphic nature of isotope stages and substages. Quaternary Science Reviews, 111: 94-106.

Roman, R., Dzieduszyńska, D., Petera-Zganiacz, J., 2014. Łódź Region and its northern vicinity under Vistulian Glaciation conditions. Quaestiones Geographicae, 33: 155-163.

Rotnicki, K., 1987. Main phases of erosion and accumulation of the middle and lower Prosna valley during the last glacial-interglacial cycle. Geographia Polonica, 53: 53-65.

Röhling, E.J., Medina-Elizalde, M., Shepherd, J.G., Siddall, M., Stanford, J.D., 2012. Sea surface and high-latitude temperature sensitivity to radiative forcing of climate over several glacial cycles. Journal of Climate, 25: 1635-1656.

Schwan, J., Miedema, R., Cleveringa, P., 1982. Pedogenic and sedimentary characteristics of a late Glacial-Holocene solifluction deposit at Hjerupgyde, Funen, Denmark. Catena, 9: 109-138.

Shanley, K.W., McCabe, P.J., 1993. Alluvial architecture in a sequence stratigraphic framework: a case history from the Upper Cretaceous of southern Utah, U.S.A. IAS Special Publication, 15: $21-55$.

Shanley, K.W., McCabe, P.J.,1994. Perspectives on the sequence stratigraphy of continental strata. AAPGs Bulletin, 78: 544-568.

Sokołowski, R., Janowski, Ł., Hrynowiecka, A., Molodkov, A. 2019. Evolution of fluvial system during the Pleistocene warm stage (Marine Isotope Stage 7) - a case study from the Błądzikowo Formation, N Poland. Quaternary International, 501: 109-119.

Sokołowski, T., Wacnik, A., Woronko, B., Madeja, J., 2014 Eemian-Weichselian Pleniglacial fluvial deposits in southern Poland (an example of the Vistula River valley in Karaków). Geological Quarterly, 58 (1): 71-84.

Starkel, L., 1997. The evolution of fluvial systems in the Upper Vistulian and Holocene in the territory of Poland. Landform Analysis, 1: 7-18.

Starkel, L., Michczyńska, D.J., Gębica, P., Kiss, T., Panin, A., Perşoiu, I., 2015. Climatic fluctuations reflected in the evolution of fluvial systems of Central-Eastern Europe (60-8 ka cal. BP). Quaternary International, 388: 97-118.

Svendsen, J.I., Alexanderson, H., Astakhov, V.I., Demidov, I., Dowdeswell, J.A., Funder, S., Gataullin, V., Henriksen, M., Hjort, C., Houmark-Nielsen, C., Hubberten, H.W., Ingólfsson, Ó., Jakobsson, M., Kjær, K.H., Larsen, E., Lokrantz, H., Lunkka, J.P., Lyså, A., Mangerud, J., Matiouchkov, A., Murray, A., Möller, P., Niessen, F., Nikolskaya, O., Polyak, L., Saarnisto, M., Siegert, C., Siegert, M.J., Spielhagen, R.F., Stein, R., 2004. Late Quaternary ice sheet history of northern Eurasia. Quaternary Science Reviews, 23: 1229-1271.

Szałajdewicz, J., 1998. Szczegółowa Mapa Geologiczna Polski w skali 1:50 000, arkusz Gostyń (in Polish). Państwowy Instytut Geologiczny, Warszawa.

Szałajdewicz, J., 2002. Objaśnienia do Szczegółowej Mapy Geologicznej Polski w skali 1:50 000, arkusz Gostyń (in Polish). Państwowy Instytut Geologiczny, Warszawa.

Törnqvist, T., 2007. Fluvial environments/responses to rapid environmental change. In: Encyclopedia of Quaternary Science (ed. S.A. Elias): 686-694. Elsevier, London.
Tylmann, K., Rinterknecht, V.R., Woźniak, P.P., Bourlès, D., Schimmelpfennig, I., Guillou, V., ASTER Team, 2019. The LOcal Last Glacial Maximum of the southern Scandinavian Ice Sheet front: cosmogenic nuclide dating of erratics in northern Poland. Quaternary Science Reviews, 219: 36-46.

Udden, J.A., 1914. Mechanical composition of clastic sediments. GSA Bulletin, 25: 655-744.

Vandenberghe, J., 2003. Climate forcing of fluvial system development: an evolution of ideas. Quaternary Science Reviews, 22: 2053-2060.

Van Huissteden, J., Kasse, C., 2001. Detection of rapid climate change in Last Glacial fluvial successions in the Netherlands. Global and Planetary Change, 28: 319-339.

Van Huissteden, J., Gibbard, P.L., Briant, R.M., 2001. Periglacial fluvial systems in northwest Europe during marine isotope stages 4 and 3. Quaternary International, 79: 75-88.

Van Vliet-Lanoë, B., Magyari, A., Meilliez, F., 2004. Distinguishing between tectonic and periglacial deformations of Quaternary continental deposits in Europe. Global and Planetary Change, 43: 103-127.

Vasil'chuk,Y.K., Vasil'chuk, A.C., Stanilovskaya, J.V., 2018. Early Holocene climate signals from stable isotope composition of icewedges in the Chara Basin, northern Transbaikalia, Russia. Geoscience Frontiers, 9: 471-483.

Ward, J.H.J., 1963. Hierarchical grouping to optimize an objective function. Journal of the American Statistical Association, 58: 236-244

Weckwerth, P., 2018. Fluvial responses to the Weichselian ice sheet advances and retreats: implications for understanding river paleohydrology and pattern changes in Central Poland. International Journal of Earth Sciences, 107: 1407-1429.

Weckwerth, P., Przegiętka, K.R., Chruścińska, A., Pisarska-Jamroży, M., 2013. The relations between optical bleaching and sedimentological features of fluvial deposits in the Toruń Basin (Poland). Geological Quarterly, 57 (1): 31-44.

Wentworth, C.K., 1922. A scale of grade and class terms for clastic sediments. The Journal of Geology, 30: 377-392.

Woronko, B., Zieliński, P., Sokołowski, R.J., 2015. Climate evolution during the Pleniglacial and Late Glacial as recorded in quartz grain morphoscopy of fluvial to aeolian successions of the European Sand Belt. Geologos, 21: 89-103.

Zieliński, P., Sokołowski, R.J., Woronko, B., Jankowski, M., Fedorowicz, S., Zaleski, I., Molodkov, A., Weckwerth, P., 2015. The depositional conditions of the fluvio-aeolian succession during the last climate minimum based on the examples from Poland and NW Ukraine. Quaternary International, 386: $30-41$.

Zieliński, P., Sokołowski, R.J., Jankowski, M., Standzikowski, K., Fedorowicz, S., 2019. The climatic control of sedimentary environment changes during the Weichselian - an example from the Middle Vistula Region (eastern Poland). Quaternary International, 501: 120-134.

Zieliński, T., 1998. Litofacjalna identyfikacja osadów rzecznych (in Polish). In: Struktury sedymentacyjne i postsedymentacyjne w osadach czwartorzędowych i ich wartość interpretacyjna (ed. Mycielska-Dowgiałło): 195-257. Wydz. Geografii i Studiów Region. Uniw. Warszawskiego. Warszawa.

Zieliński, T., 2007. The Pleistocene climate-controlled fluvial sedimentary record in the Bełchatów mine (central Poland). Sedimentary Geology, 193: 203-209.

Zieliński, T., 2017. Sedymentologia. Osady rzek i jezior (in Polish). Wydawnictwo Naukowe UAM, Poznań.

Żarski, M., Winter, H., Kucharska, M., 2018. Palaeoenvironmental and climate changes recorded in the lacustrine sediments of the Eemian Interglacial (MIS 5e) in the Radom Plain (Central Poland). Quaternary International, 467 (A): 147-160. 